Article

\title{
Smart Urban Planning: Evaluating Urban Logistics Performance of Innovative Solutions and Sustainable Policies in the Venice Lagoon-the Results of a Case Study
}

\author{
Marco Mazzarino ${ }^{1, *}$ and Lucio Rubini ${ }^{2}$ \\ 1 Dipartimento di Culture del Progetto, Università IUAV di Venezia, Ca' Tron—Santa Croce 1957, \\ 30135 Venice, Italy \\ 2 Tedis Program-Sustainable Logistics Unit, Venice International University, Isola di San Servolo, \\ 30133 Venice, Italy \\ * Correspondence: mazzarin@iuav.it
}

Received: 21 June 2019; Accepted: 20 August 2019; Published: 23 August 2019

\begin{abstract}
Currently, remarkable gaps of operational, social and environmental efficiency and overall sub-optimization of the logistics and mobility systems exist in urban areas. There is then the need to promote and assess innovative transport solutions and policy-making within SUMPs (Sustainable Urban Mobility Plans) to deal with such critical issues in order to improve urban sustainability. The paper focuses on the case study of the Venice Lagoon, where islands-despite representing a relevant feature of urban planning-face a tremendous lack of accessibility, depopulation, social cohesion and they turn out to be poorly connected. By developing an original scenario-building methodological framework and performing data collection activities, the purpose of the paper consists of assessing the feasibility of a mixed passenger and freight transport system - sometimes called cargo hitching. Mixed passenger and freight systems/cargo hitching are considered as an innovative framework based on the integration of freight and passenger urban systems and resources to optimize the existing transport capacity, and thus, urban sustainability. Results show that the overall existing urban transport capacity can accommodate urban freight flows on main connections in the Lagoon. The reduction in spare public transport capacity, as well as in the number (and type) of circulating freight boats show-in various scenarios-the degree of optimization of the resulting urban network configuration and the positive impacts on urban sustainability. This paves the way for the regulatory framework to adopt proposed solutions.
\end{abstract}

Keywords: urban freight transport; urban logistics performance; urban mobility; mixed passenger and freight transport; cargo hitching; innovative policies; smart solutions; sustainability; Venice Lagoon

\section{Introduction}

Currently, remarkable gaps of operational, social and environmental efficiency and an overall sub-optimization of the mobility and logistics systems exist in urban areas [1,2]. There is then the need to promote and assess innovative business models and policy-making within SUMPs to deal with such critical issues in order to improve overall urban sustainability. Our paper proposes an original scenario-building methodological framework to assess the feasibility of a mixed passenger and freight transport system - sometimes called cargo hitching - in the Venice Lagoon. In particular, the connections to/from the peripheral urban areas (the islands) are considered. In fact, despite representing a relevant feature of urban planning - indeed, stated by the Special Law of Venice - the islands of the Venice Lagoon face a tremendous lack of accessibility, depopulation, social cohesion and they turn out to be 
poorly connected (transit times to/from the islands are definitely high-in a range of an hour or more-, thus, they represent a strong constraint for the development of an effective and efficient passenger and logistics system). Effective and innovative SUMP measures and business models-supported by suitable data sets and a modern regulatory framework-are needed to address such issues.

The paper (based on the results of the EU Project "NOVELOG" (New Cooperative Business Models and Guidance for Sustainable City Logistics)) aims at identifying and assessing more sustainable—and operationally efficient—urban mobility solutions based on innovative business models to improve the accessibility and liveability of urban remote areas (the islands) —which are characterized by high environmental sensitivity and touristic attractiveness-while fostering their economic development. In particular, the paper considers two policy dimensions of urban transport "integration" to foster a polycentric urban development and promote a single integrated urban transport network (SUMP framework):

- A "horizontal" geographical integration, between core and peripheral urban areas (historical city center and the islands);

- A "vertical" (functional) integration, between two urban mobility systems, namely freight and passengers.

Moreover, concerning governance issues, the cooperation between the Municipality (in charge of urban planning in the historical city center) and the Metropolitan City (in charge of the planning of the overall Lagoon) is promoted.

The goal of the paper is achieved by collecting, analyzing and assessing data and information according to an effective urban mobility and logistics planning (scenario-building) approach consisting of the following steps:

- Developing the "as is" scenario (mapping and replicating the existing urban logistics and mobility networks and configurations);

- Identifying critical issues and opportunities for innovative policy actions and business models (mixed passenger and freight transport solutions/cargo hitching);

- Developing "to be" scenarios (simulating and assessing innovative solutions).

Within such a framework, a strategic feasibility evaluation of innovative transport services in the Lagoon is carried out as a preliminary step to promote further policy actions. Targeted policy priorities related to innovative business models—-to be seen as components of the forthcoming SUMP-consist of the identification of mixed passenger and freight/cargo hitching opportunities on core-periphery connections to improve the Venice Lagoon urban transport performance and overall sustainability. Mixed urban transport solutions/cargo hitching represent a rather newly developed research field aiming at integrating freight and passenger transport systems at the urban and metropolitan level. Social and environmental goals (which are not only at stake by local stakeholders, but also explicitly stated in the Special Law for the Venice Lagoon) are to be achieved in the economic most viable way by optimizing the existing urban mobility system capacity via innovative business models, thus, increasing the overall sustainability of the urban setting.

More specifically, two kinds of policy goals are pursued:

- At a strategic and regulatory level, a new urban logistics network design is envisaged, which is given by an optimized extended/distributed logistic network improving the accessibility of the islands (local stakeholder priorities consist of "keeping the Lagoon alive, not just the historical city center") and the overall environmental system;

- At a tactical/operational level (business model), the mixed transport/cargo hitching solutions are promoted and assessed.

The paper is organized as follows. First, a rather comprehensive literature review is performed on the topic of mixed passenger and freight transport systems, including cargo hitching. Literature 
review depicts the state-of-the-art of the field and highlights major gaps and opportunities, which are then addressed in our paper. Secondly, data requirements are discussed as they relate to our case study, and overall methodology design is presented for data analysis. Next, main results and overall scenario assessment about the feasibility of the integrated (passenger/freight) urban mobility and logistics system are discussed. Finally, some conclusions are drawn looking at broader implications for future research, including study limitations and implications for various urban contexts.

\section{Mixed Passenger and Freight Urban Transport Systems: A Literature Review}

The literature on SUMPs and sustainable city logistics planning and management highlights main components of urban mobility plans, relevant stakeholders and major issues [3-8], along with the elements to include urban logistics in urban plans [9,10]. When addressing urban logistics, the concepts of logistics pooling, resource sharing [1,2,10-12] and mixed passenger and freight transport planning $[1,13]$ are introduced. Moreover, a growing literature addresses the principles of cargo hitching [14-17]. Mixed passenger/freight transport systems and cargo hitching represent innovative approaches to urban mobility [13], which are linked to the sharing economy $[10,12,13,18,19]$ and overall smart city paradigms [20-25]. In the urban environment, passenger and freight flows and systems co-exist to compose the complex system of urban mobility [13]. Van Duin et al. [16] underline that the term "sharing economy" consists of the collaborative consumption made by activities of sharing, exchanging and rental of resources. Modern examples are those of Uber, Blablacar and AirBNB as sustainable usage of resources. In addition, some urban transport operators-e.g., DHL—are trying to implement such a concept for city logistics [26]. Main objectives of mixed/cargo hitching solutions consist of the redesigning of the "integrated people and freight synchromodal transportation networks and related planning and scheduling policies to enable efficient and reliable delivery of each parcel and retail delivery" [27]. The idea is to combine freight and passenger flows and urban network resources (infrastructures, vehicles, etc.) [13] to gain more efficiency (and hopefully effectiveness) of the overall urban mobility system, with regards to both central and peripheral areas. In other words, there is the need to consider the urban freight and passenger transport systems in a more holistic manner, that is, as a single urban mobility system [28]. Traditionally, freight and passenger systems are considered separately, and they are subject to different regulatory regimes $[16,29,30]$ - a mostly "deregulated" model for freight, and a "public" model for passengers. On the contrary, a unified approach should be employed by policy-makers to deal with the two transport systems [1,31]. Related policy measures could consist of $[32,33]$ :

- models of shared infrastructures, both linear (for instance, road spaces) and nodal (for instance, UDCs (Urban Distribution Centers), parking spaces, terminals);

- $\quad$ models of shared vehicles and transport means.

Mixed transport solutions/cargo hitching are not a completely new topic. The idea of outsourcing parts of the delivery process - in this case, public transport with a surplus in capacity—has already been around for decades for what concerns, for example, long-haul air and rail operations, where a mixed usage of aircraft or trains is nothing unusual [17]. The innovative aspect of urban mixed transport solutions/cargo hitching lies in that it proposes the usage-when available —of overcapacity of public transport to carry freight for short-haul operations, mainly in urban or peri-urban areas with a shrinking population $[27,34]$.

First hints about a shift towards shared passengers and freight urban transport systems were given by the European Commission in 2007 [29]: “Urban freight distribution could be better integrated within local policy-making and institutional settings. Public passenger transport is usually supervised by the competent administrative body while freight transport distribution is normally a task for the private sector. Local authorities need to consider all urban logistics related to passenger and freight transport together as a single logistics system" [35]. Trentini et al. [30] quickly reacted to this by producing a comprehensive list of projects focusing on sharing "public transport services, public 
road space or existing urban areas", which can be considered as precursors of subsequent concepts of mixed solutions and cargo hitching. In particular, the principles of cargo hitching have initially found a sound theoretical framework mostly in The Netherlands, especially at the Universities of Groningen [36], Twente, Eindhoven [37,38], Rotterdam [39], Breda [40] and the national research center of DINALOG [17]. Currently, a growing body of scientific literature can be recognized [14-16,41].

Mixed transport/ cargo hitching solutions significantly improve environmental, economic and social aspects, as well as sustainability and accessibility of urban and peripheral contexts. Authors have worked mostly in urban areas $[17,30,31,33,37]$, while the literature on projects in peripheral and rural areas is rather scant [27]. However, the impacts of such solutions prove to be particularly positive in low urbanized and remote urban areas [16], since local public transport companies find incentives to improve the utilization of public transport.

In the literature and in practice, a number of case studies and projects can be found in Europe and elsewhere about mixed transport/cargo hitching solutions, namely:

- Barcelona: Shared road spaces-parking spaces are used as loading/unloading bays during night hours (such solutions have been developed within the CIVITAS and MIRACLES EU Projects);

- Paris: Shared delivery bays-parking spaces used as DCs (such solutions are now structurally embedded in the urban system);

- London: Trials of an innovative freight-passenger vehicle called Freight*bus;

- Dresden (CarGo Tram - the service has been operated since 2000, and it has recently seen a renewed development, due to the interest of VW in the field of electric mobility), Amsterdam [42] (Cargo Tram) (based on the idea of Dresden, a pilot project started by CityCargo Amsterdam in 2007 [16]. However, it went bankrupt in 2009, due to a lack of public subsidies), Zurich (the service has been operated since 2003), Saint-Etienne (as for Saint-Etienne, see also https://amp.theguardian.com/sustainable-business/2017/jul/21/electric-trams-cities-grocerieseurope-edinburgh-dresden). The French experience started in 2010 and it has consisted of various tests—both in Paris and elsewhere (TramFret) — carried out until 2017 to deliver goods in urban areas using public transport systems. As for the Saint-Etienne case, an urban distribution system for retail goods has been in place thanks to the cooperation between the Municipality, the public transport operator and a large retailer, Casino): Shared trams-using trams for freight transport;

- Masdar City: The Freight Rapid Transit project (the project is to be developed through pilot actions, and it has been included in the new Urban Plan of Masdar City in connection with the development of the Personal Rapid Transit system. The goal is to operate some 5000 transits using 810 vehicles carrying payloads of maximum 1600 kilos for residents and local economic activities);

- Brandeburg: The KombiBus service carrying passengers and delivering goods in peri-urban areas (it is a regular service, which has recently raised the interest of other Lands);

- Groningen: Integrated urban services for passengers and small parcels (books, magazines, medicines) (consisting of pilot activities within an EU project on cargo hitching led by the University of Eindhoven. It involves the local public transport operator (Connexxion), Biblionet and the local taxi service company (Regiotaxi));

- District of Heisenberg: The «MultiBus» project within the MULI Buslorry project (a regular service), in which the small cities of Gangelt, Selfkant, Waldfeucht are involved;

- Sweden: The Bussgods service (see http://www.bussgods.se/om-oss);

- India: The Dabbawala system [43].

A rather significant on-going experience-led by the Transport for London, Department of City Planning-consists of the implementation of cargo hitching solutions along the Thames. The local public transport operator is being integrated with a cluster of freight transport operators. The quality of service-measured in terms of travel times for passengers-turns out to be attractive for freight operators. Thus, combined freight-passenger services are being developed. The project is focusing on selected type of deliveries, and it foresees the use of loading/unloading models based on roll-on/roll-off 
systems, which must not interfere with passenger transport (average operational time is expected in the range of three minutes). The city of London supports the initiative, with the aim of reducing the number of circulating vehicles.

Some sample pictures of various projects and case studies are shown below (Figures 1-6).

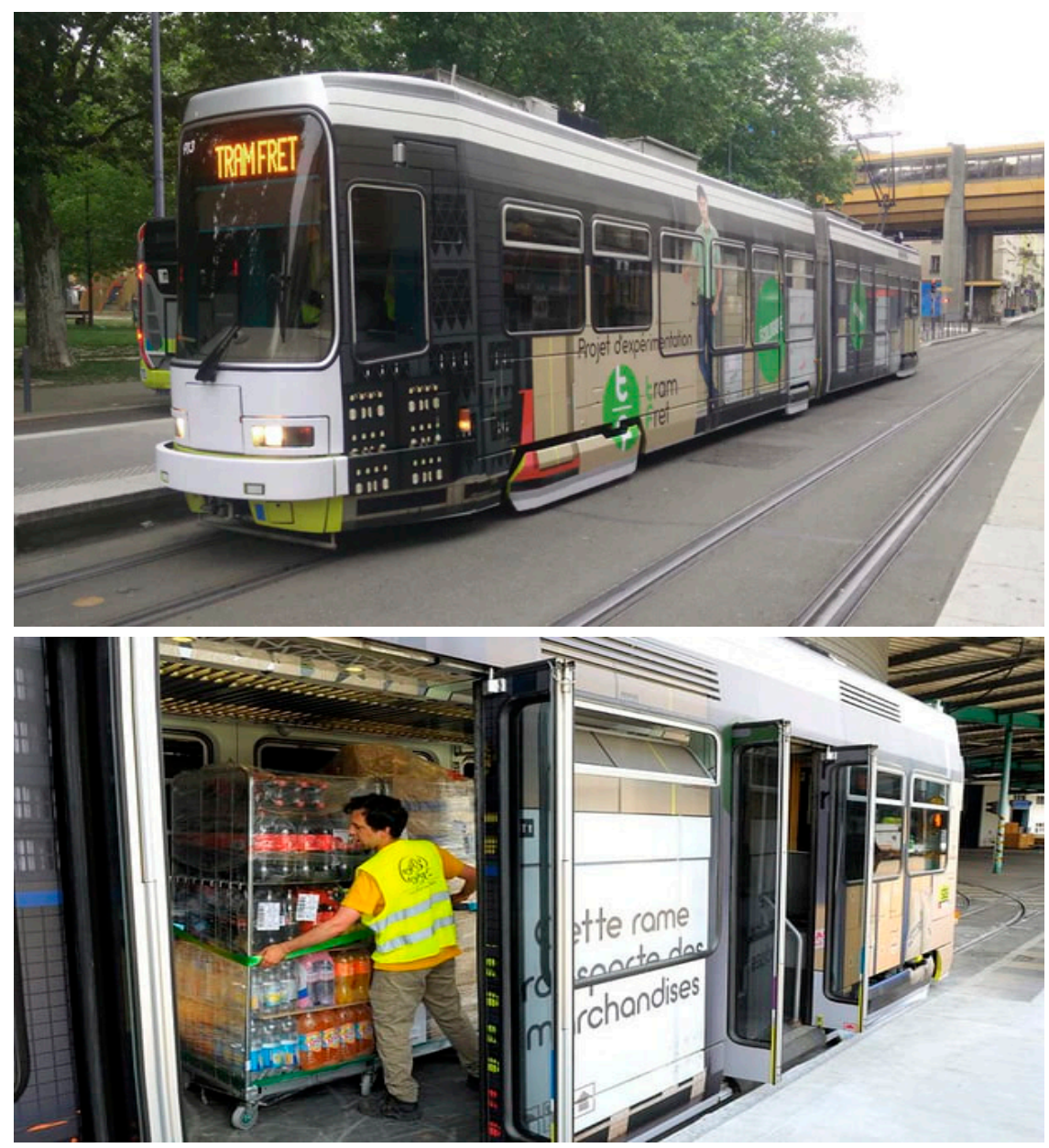

Figure 1. The Saint-Etienne case.

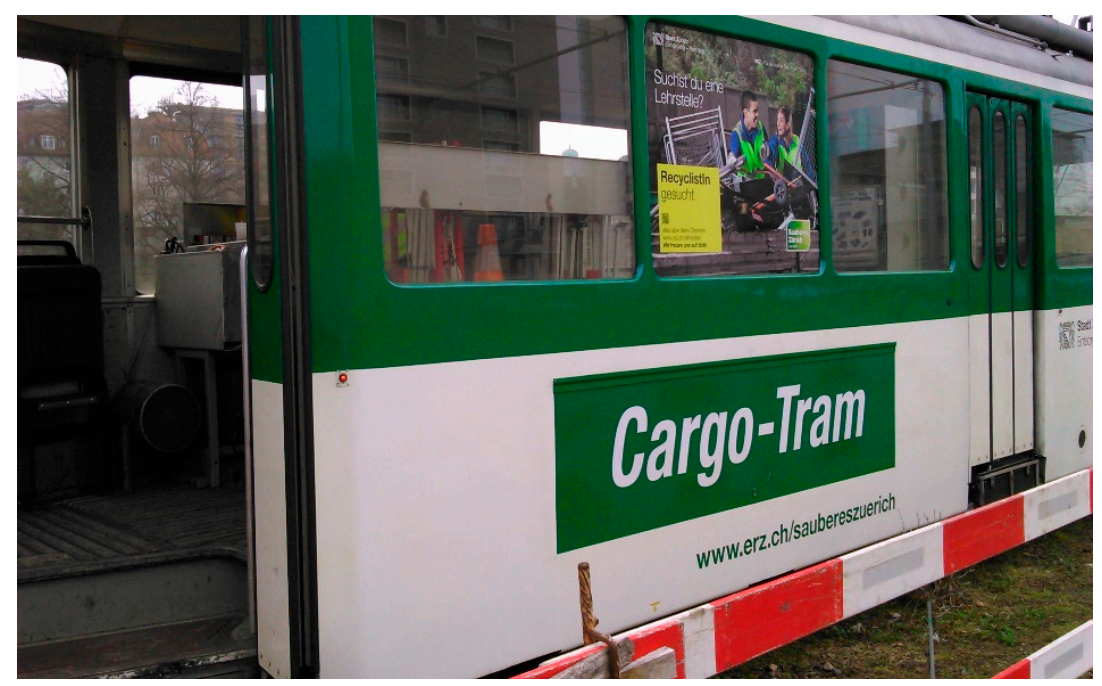

Figure 2. The Zurich case. 


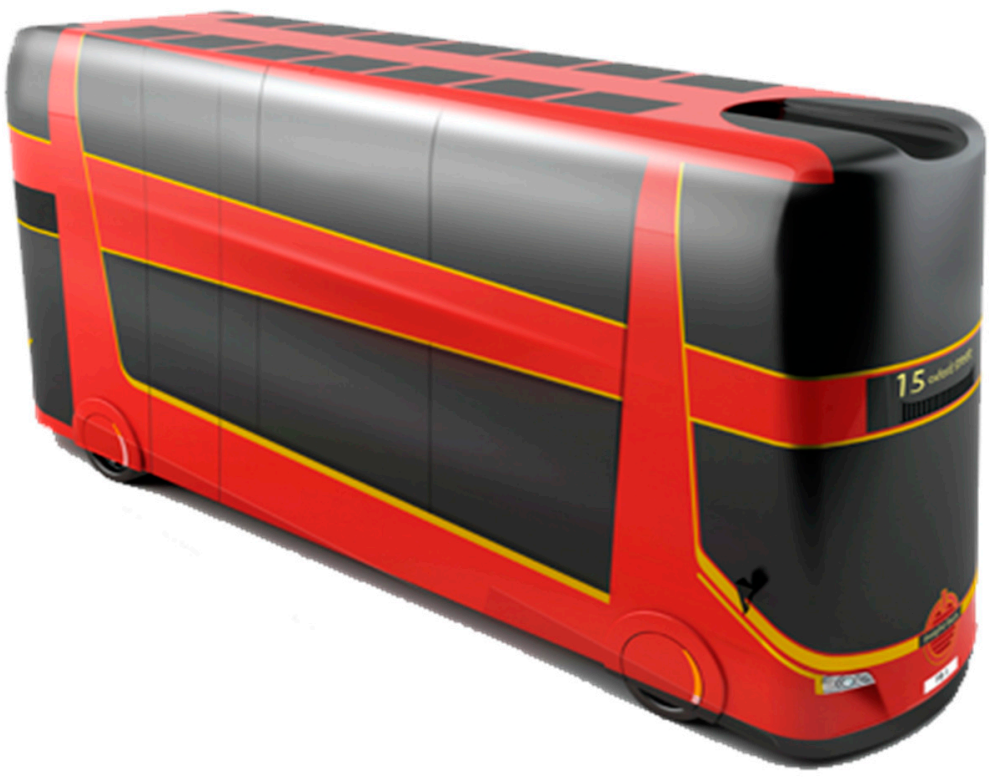

Figure 3. The London vehicle concept.

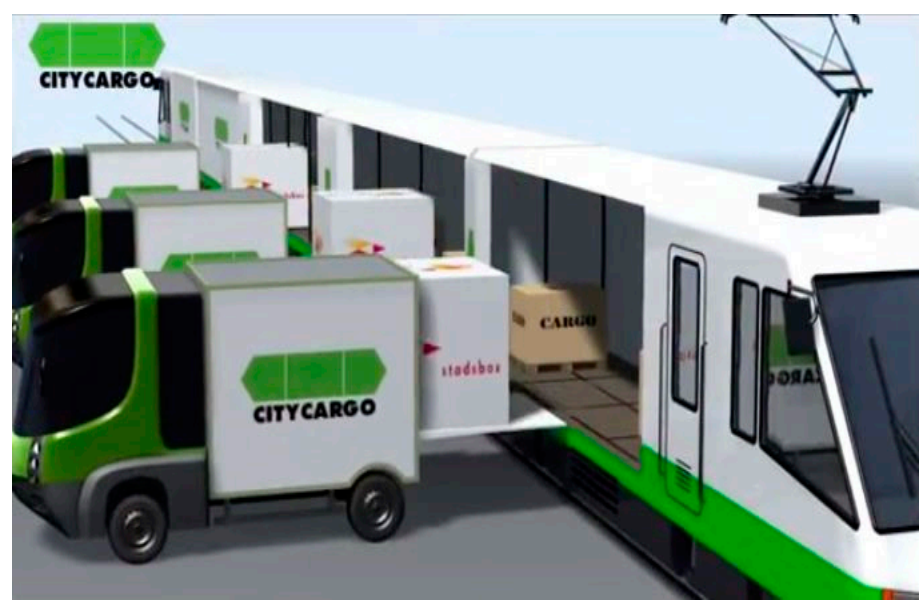

Figure 4. The Citycargo case in Amsterdam.

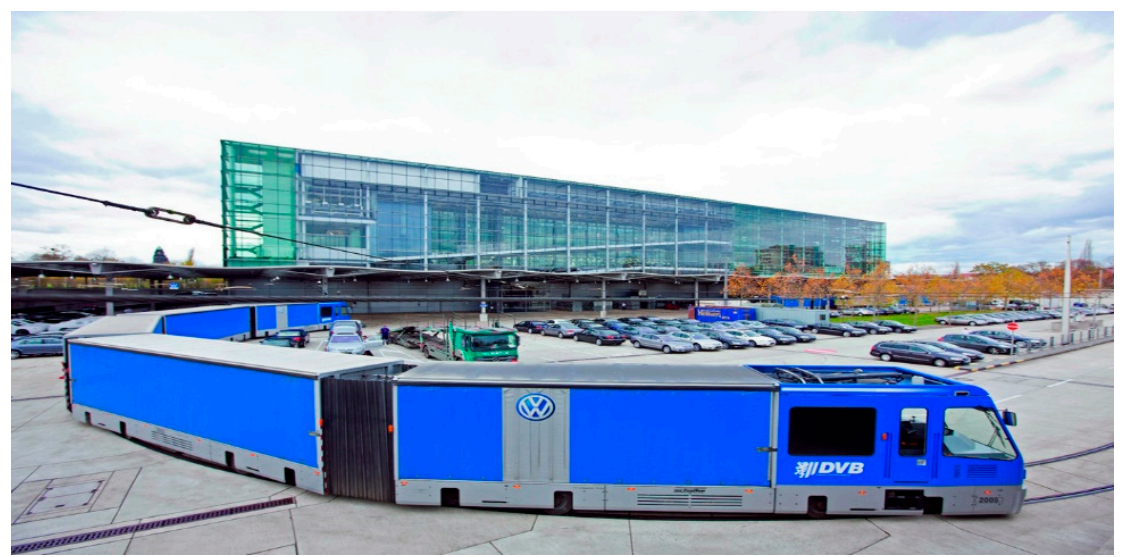

Figure 5. The Dresden case. 

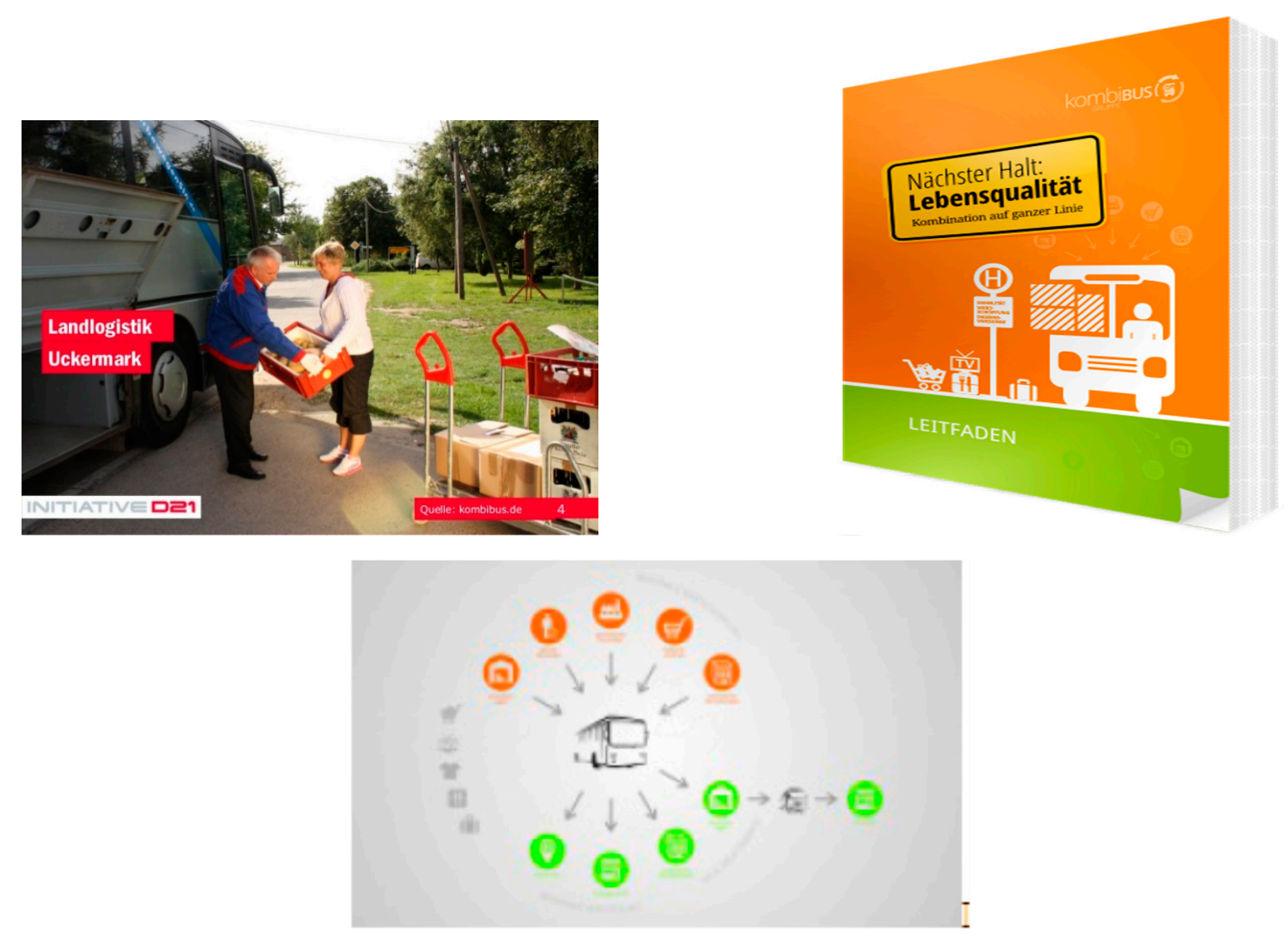

Figure 6. The Brandeburg case.

A recent paper by Van Duin et al. [16] presents the results of the Cargo Hitching project in the Netherlands [44], which is based on the Transport Capacity Sharing concept. It aims at optimizing the existing unused capacity of public transport by carrying freight (in particular, parcels). The project involves a group of Dutch universities, government agencies and private companies and the national government funds it. The small village of Millingen aan de Rijn, close to the city of Nijmegen in the Eastern part of the country bordering with Germany, was identified to test cargo hitching solutions in 2017. Pilot actors consist of Binnenstadservice (BSS) - the logistics operator managing the local urban hub-, Breng-the local public transport company, belonging to the Connexxion group —and Pluryn-a local agency providing workers. BSS is in charge of transporting parcels from the urban logistics hub to Nijmegen city center and the bus station, while Breng operates two bus lines connecting Njimegen to Millingen carrying mostly children and students.

The available capacity of public transport to carry parcels—-by using roller containers or trolleys-is firstly estimated and the overall business model designed. BSS consolidates parcels from different carriers at its logistics hub and subsequently moves them to Njimegen Central Station (Berg office). Then, workers (provided by Pluryn) travel with the parcels using the bus lines to Millingen aan de Rijn, where they are stored at a Cargo Hitching service desk. Eventually, final customers/receivers-usually, local residents and businesses-take their parcels from the depot according to predefined time windows. Additional customers can consist of carriers and shippers (e.g., DHL), looking for cost reductions deriving from the overall cooperative business model. Very last-mile deliveries (home deliveries) can also be made by bike. During the pilot project, the local demand for parcels was calculated, since it represents a critical aspect for the business model viability. Peak-level demand-representing the "high" scenario-was estimated at around 300 parcels/day. Overall results eventually show relative viability of cargo hitching solutions and significant environmental benefits in terms of $\mathrm{CO}_{2}$ reductions. 
In the main, integrating passenger and freight transport at an urban and metropolitan level should be considered a promising approach $[16,45]$. Authors have already been able to identify some of the drivers for the success of such an innovative transport system, as well as some of the drivers that are keeping its diffusion to a halt $[46,47]$. Among the key factors determining the success of mixed/cargo hitching solutions, the most significant one is probably its economic attractiveness for all stakeholders involved in the supply chains. Supply chain actors-including manufacturers, shippers, carriers and receivers-generally benefit from consolidation activities. Seemingly, local public transport operators get advantages by optimizing exceeding capacity to transport parcels and small cargo units. Finally, public stakeholders benefit from improved sustainability of the overall urban mobility system and from the provision of fewer subsidies.

Importantly, while making transport operations cheaper, mixed/cargo hitching solutions realize social benefits by serving remote areas with a shrinking population in a more economical way, thus, enhancing accessibility, liveability and overall sustainability [27,34]. At the same time, remarkable environmental benefits are realized as well thanks to less driven mileage by cargo vehicles and consequently fewer pollutants. Clearly, fewer cargo vehicles constitute an improvement of the urban quality of life.

Mixed transport solutions/cargo hitching, however, imply a significant change in today's operations, policy-making and theoretical approaches to urban mobility. In most cases, the regulatory and legislative systems (at all levels) are not shaped to incentive such advanced sharing initiatives [27]. Cargo and passengers transport systems are considered as separated entities, since they are regulated by different authorities, rules and guidelines.

According to [13], further research is needed to assess the overall feasibility in terms of the efficiency of integrated transport solutions and business models $[13,30,48,49]$ and case study experiments are required. Moreover, there is a lack of real-life applications, and still few cities have considered an integrated passenger and freight system [1]. Mostly, mixed/cargo hitching projects in Europe tend to remain at the conceptual level, while evaluation and experimentation in specific urban contexts are necessary [2,4]. Additionally, it is important to provide insights into the feasibility as a preliminary step to further studies, eventually implementing revised regulatory measures [1]. Research efforts should foster integration at both an institutional-by promoting the necessary changes of the regulatory framework—and business level—by developing sustainable business models [16]. The main challenge consists of the need to ensure that the transition towards an integrated urban system is made it smooth by solving regulatory issues. The preliminary assessment of the feasibility of an integrated system constitutes a key element (a sine qua non condition). Funding by public authorities and the design and implementation of pilot initiatives are also fundamental elements in the development strategy for mixed/cargo hitching solutions: Small-scale applications (e.g., in a restricted sector of an urban agglomeration or in a limited-size rural area) could be the key to test proposed models, thus, allowing to build an appropriate and reliable set of indicators and operational models to facilitate future broader diffusion of proposed solutions (incidentally, authors are working on such testing activities in some other urban contexts, namely, in Padua and Trieste). In any case, mixed transport/cargo hitching solutions must be seen as a key policy option and business model to build a more economically and environmentally efficient integrated transportation system, not only in dense areas, but particularly in more remote areas suffering from shrinking population, poor logistics services and high operational costs. Such solutions allow for consistent cost reductions through consolidation and reduction in the number of circulating vehicles, thus, making public transport services economically (more) sustainable.

To conclude, mixed passenger and freight/cargo hitching systems definitely show a significant potential, but needs to be theoretically and operationally tailored to the context of the application so that its advantages and drawbacks can be identified to obtain desirable results for private operators, public companies, institutions and users.

Based on evidences, gaps, and opportunities in the literature, our paper explores the feasibility of mixed passenger and freight transport/cargo hitching solutions in the extended urban context of 
Venice (historical city center-islands connections), where no simulations and assessment have been performed so far. It then provides useful insights both from a policy-making and research point of view.

\section{Materials and Methods}

\subsection{Data Requirements}

In order to proceed with data collection [50], analysis and scenario-building activities, a sound methodological framework is first employed to represent the urban logistics network $[51,52]$. We consider the following logistics components with specific reference to island connections:

- Urban logistics nodes (location, type, etc.);

- Flows (in particular: Main origins-destinations, main customers and suppliers, ADTs (average daily traffic), routing and scheduling patterns-including hourly distribution of logistics activities-load factors, seasonality issues, transit times, type of goods (considering primary and secondary type of goods), quantities (estimated on the basis of load factors), distribution logistics strategies, type of transport (own account/third-party), etc.);

- Quality/level of logistics customer service;

- Fleet composition (type and size/capacity of boats (estimated in cubic meters), operational hours, fuel consumption, crew requirements, etc.).

Data requirements of freight urban mobility in Venice show significant gaps, in particular as far as island connections are concerned. As a matter of facts, information availability on the main logistics variables is definitely scarce. Moreover, a large proportion of information coming from secondary sources (statistics) - indeed reliable - turns out to be outdated (in particular, most relevant statistics data is from COSES: "Rilevazioni del Traffico Acqueo Lagunare". Data covers the overall Lagoon and all kind of transport systems. Such sources are the basis of various planning documents and studies, such as the study of the Venice Municipality "Valutazione del Centro Logistico di Interscambio Merci Venezia Tronchetto", carried out by FIT Consulting, and the TRANSCARE study "City logistics Venezia"). Statistics mostly report average daily traffic on selected sections-which is indeed valuable information-however, a number of relevant logistics and transport variables is thereby missing. To fill such gaps, the authors firstly carried out an on-the-field data collection campaign. In particular, it consisted of:

- Interviewing logistics operators specialized in operations related to connections to/from the islands. Basically, all major operators were face-to-face interviewed (Overall, some five logistics operators manage the overall market. We interviewed three of them, accounting for some $70 \%$ of total market share);

- Collecting data at a significantly disaggregated level at the main urban logistics platforms through observations/surveys. Such activities were performed in close cooperation with local logistics operators and their associations (actually, since most of the data is to be considered as sensitive, we were able to perform such activities based on some confidentiality agreement (also addressing data disclosure issues) ensuring the necessary operational support by main logistics operators' associations. Public bodies (in particular, the Metropolitan City) was also involved in the research (as an associate partner).

Based on authors' knowledge, no previous information at such level of details was available in Venice; thus, the research represents a unique and original outcome, providing high added-value original data and information and insights into policy-making and logistics operations.

\subsubsection{Focus: Data Campaign at Major Urban Logistics Platforms}

A 54 hours-campaign was performed at major logistics and transshipment nodes in Venice (Tronchetto, Scomenzera, Rio dell'Arzere, San Giuliano, Treporti) during June 2017 (Figures 7-11). Data 
collection was carried out during weekdays — in particular, on Thursdays and Fridays-being June a representative high-season month. Daily activities were performed from 03:00 to 20:00, totaling in 17 daily hours in each urban node. Overall, some 550 boats (observations) were surveyed out of existing 1600 detected in Venice. Remarkably, given that some 330 third-party providers' boats are registered in Venice, our observations report the analysis of a significant share of own-account transportation in Venice. This kind of information was not previously available in Venice, and thus, it represents a significant added value for operators and policy-makers. A Google Form and an ad hoc app supported the surveys in order to collect data in real-time.

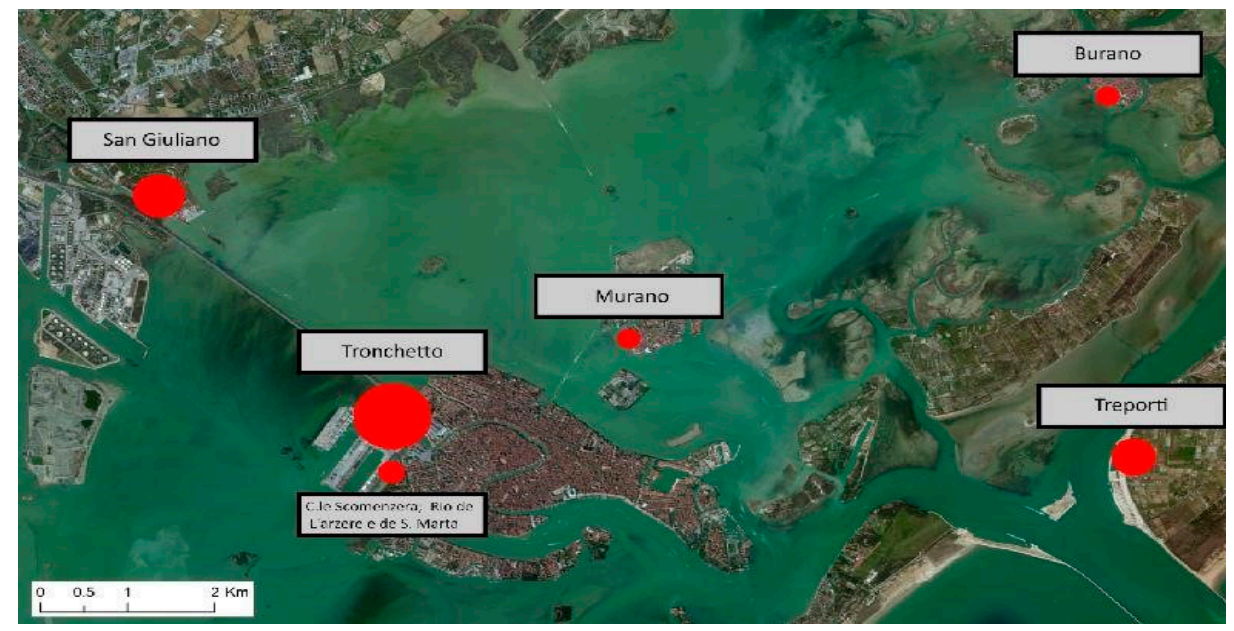

Figure 7. Location of surveyed urban logistics platforms.

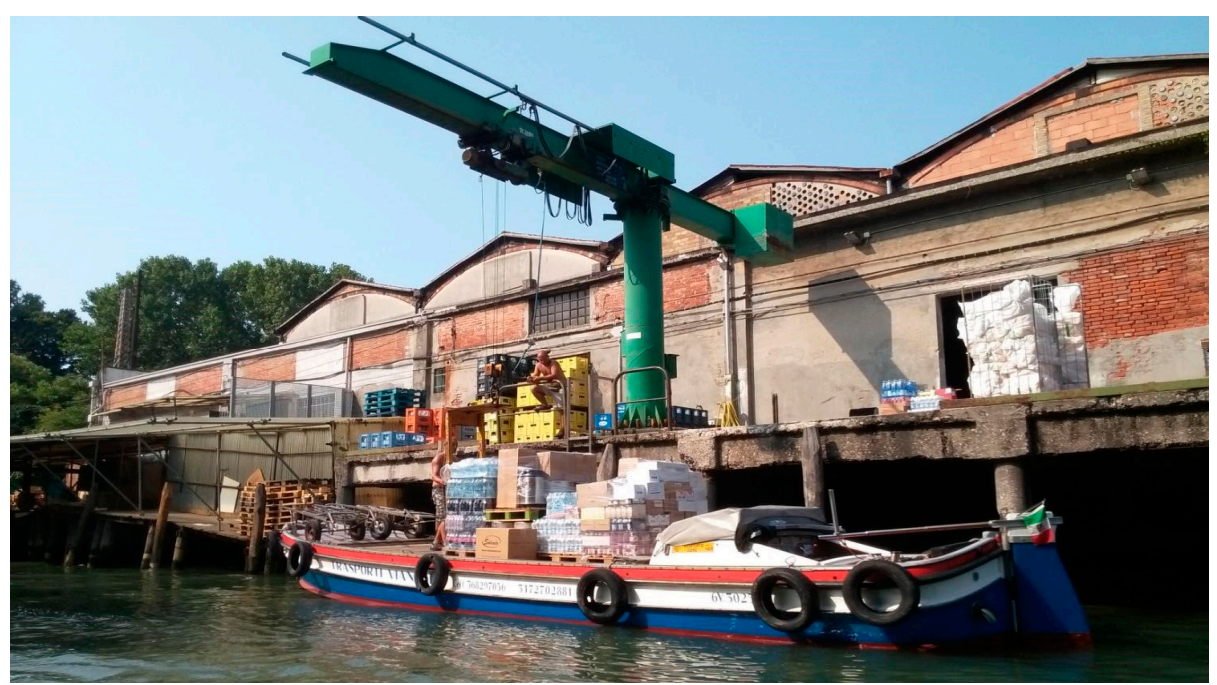

Figure 8. Rio de L'arzare urban logistics node. 


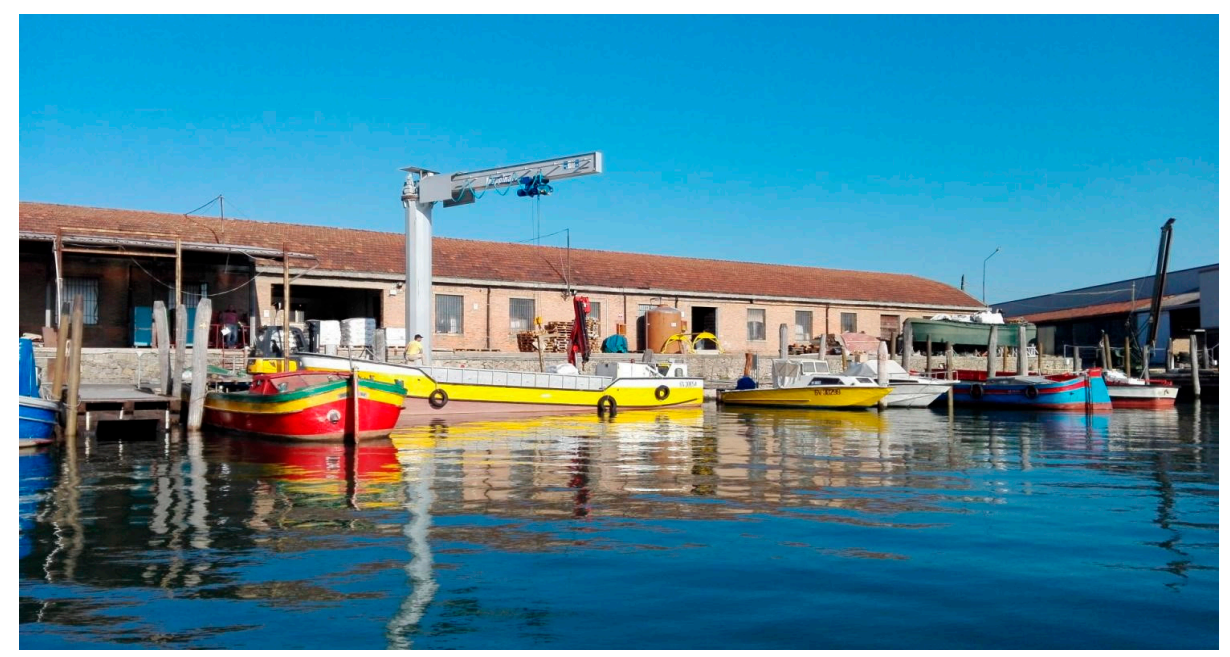

Figure 9. San Giuliano urban logistics node.

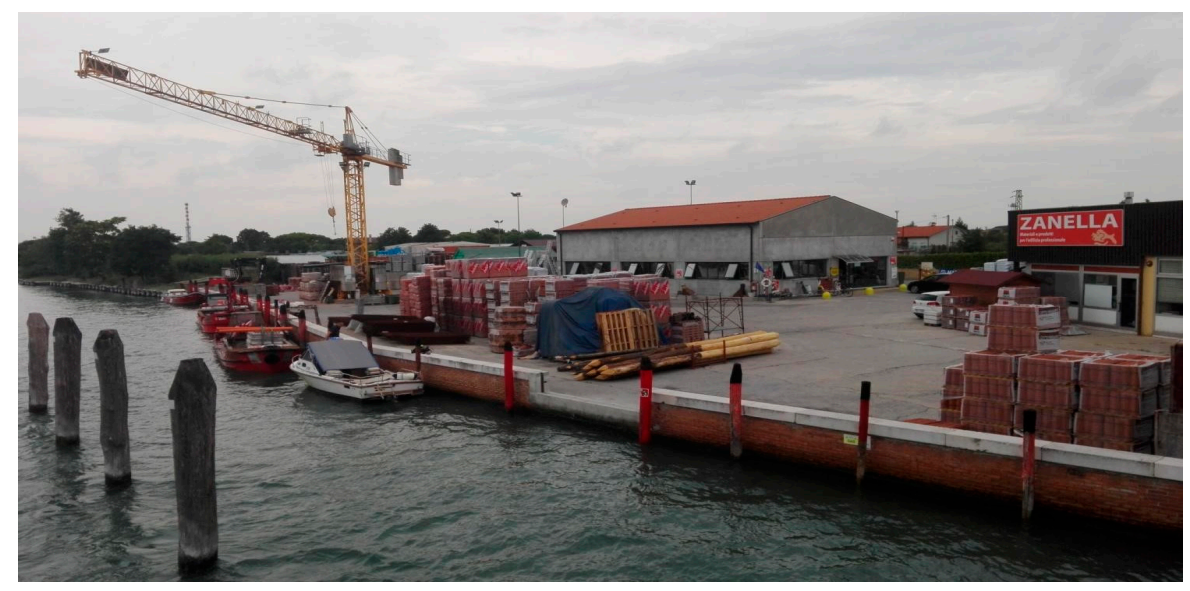

Figure 10. Treporti urban logistics node.

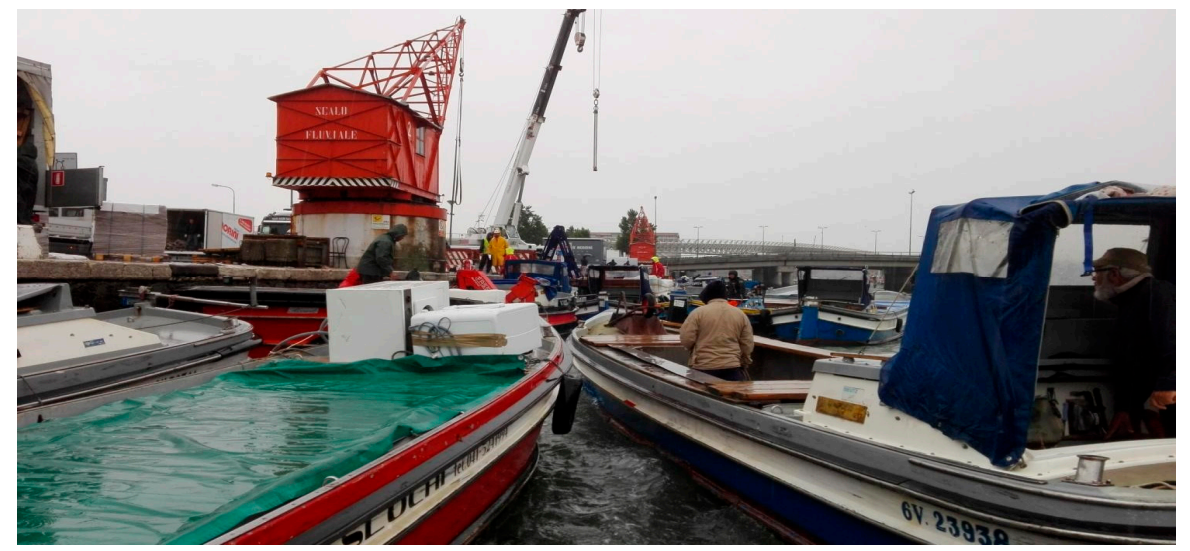

Figure 11. Cont. 

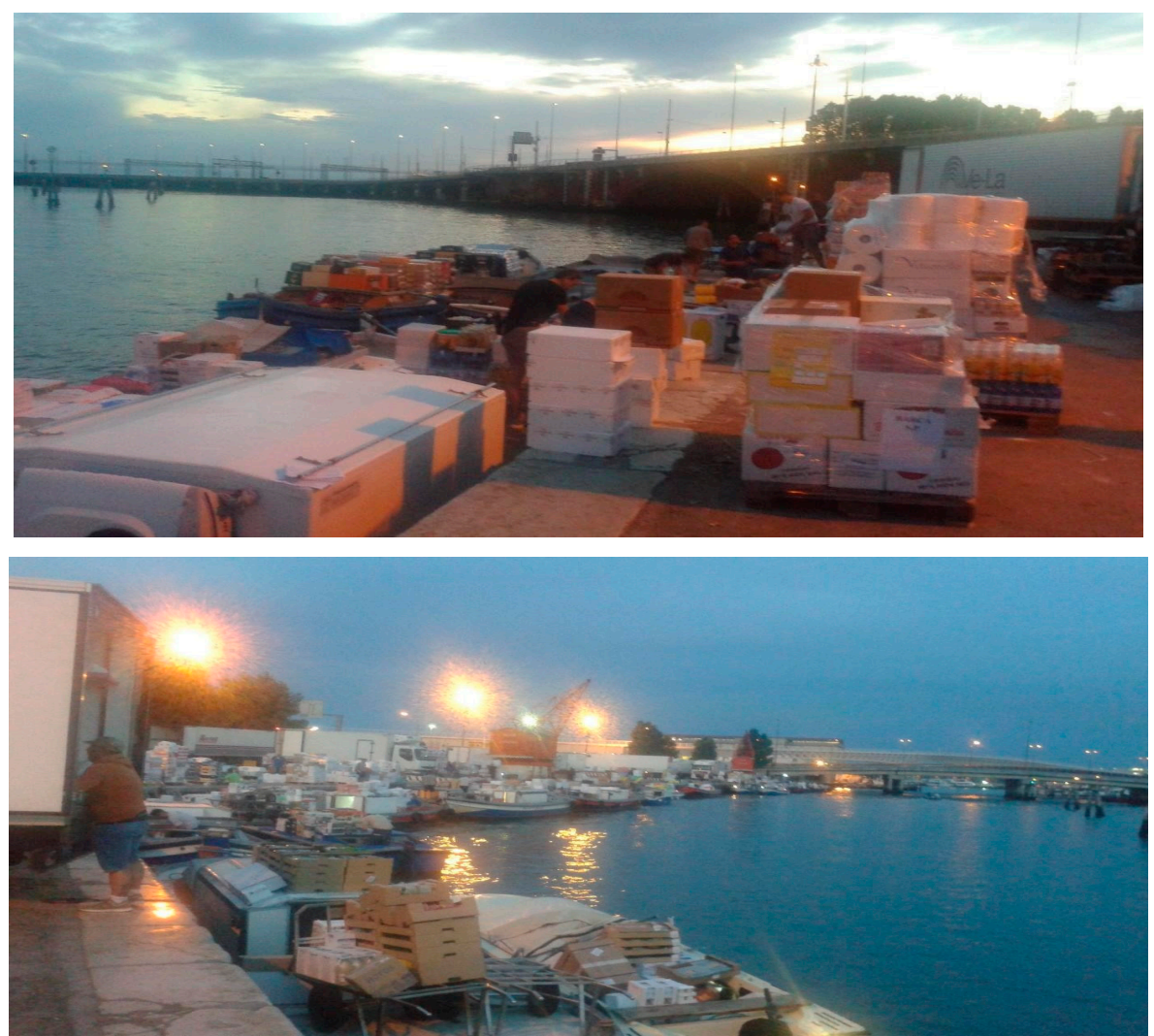

Figure 11. Tronchetto main urban logistics platform.

\subsubsection{The Public Transport Network}

According to mixed passenger and freight transport/cargo hitching principles, on top of freight transport data and information, data about the existing public transport network must be collected as well. Data and information basically include:

- Major lines and routes in the research area;

- Type of ships employed;

- Overall supply (No. seats);

- Average occupancy rates.

Figure 12 and Table 1 show the relevant features of the network.

Table 1. Main features of urban public transport.

\begin{tabular}{cc}
\hline Type of Ship & Overall Supply (No. Seats) \\
\hline “Motobattello foraneo" & 325 \\
Traditional "Vaporetto" & 218 \\
Single driver speedboat & 40 \\
\hline
\end{tabular}

\begin{tabular}{cccc}
\hline Lines & Type of Ship & Summer & Winter \\
\hline 9 & Motobattello foraneo & $\mathrm{X}$ & \\
9 & Single driver speedboat & & $\mathrm{X}$ \\
12 & Motobattello foraneo & $\mathrm{X}$ & $\mathrm{X}$ \\
13 & Single driver speedboat & $\mathrm{X}$ & $\mathrm{X}$ \\
13 & Vaporetto & $\mathrm{X}$ & $\mathrm{X}$ \\
NLN & Single driver speedboat & $\mathrm{X}$ & $\mathrm{X}$ \\
\hline
\end{tabular}




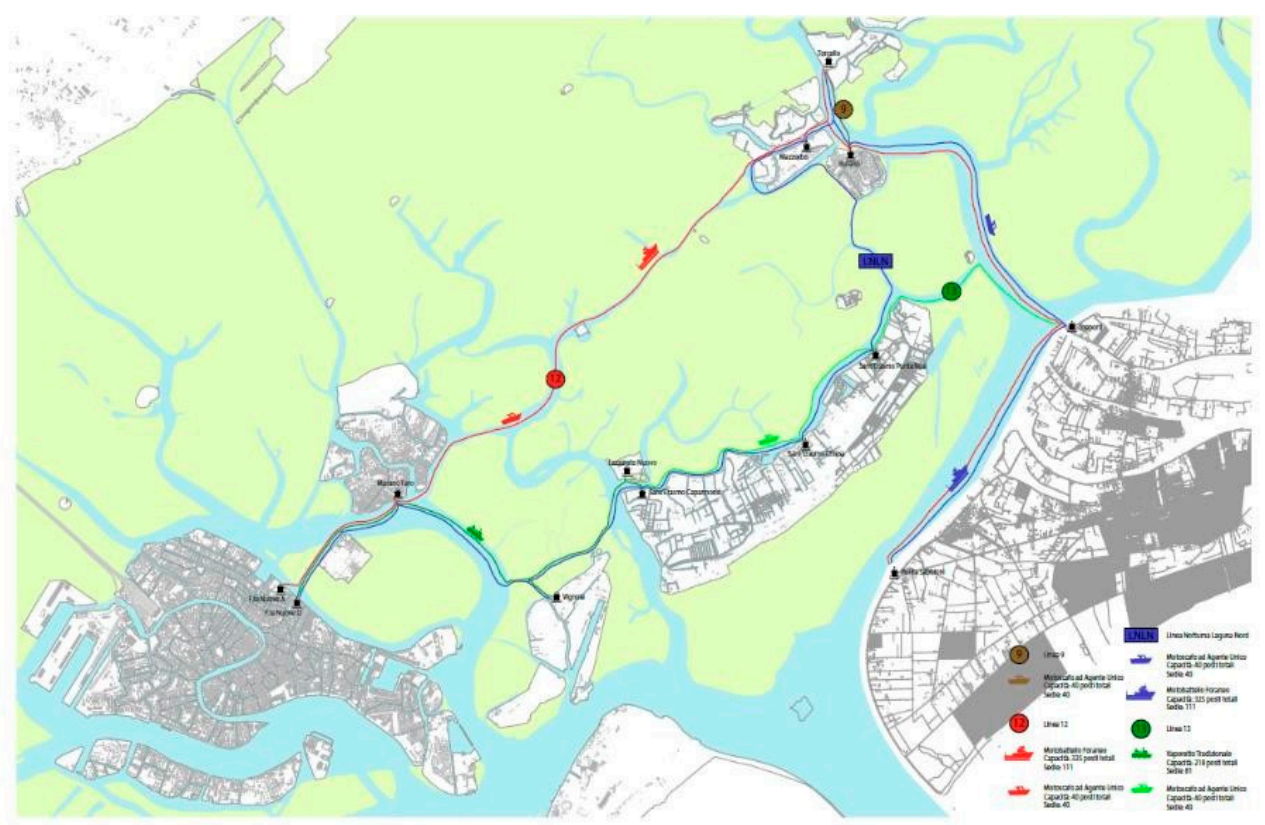

Figure 12. Main public transport routes in peripheral urban areas

Figure 13 reports the average occupancy rates for the main public transport lines in the research area (average occupancy rates are provided by the local public transport company (ACTV) as mean daily values (estimated over the year). Overall ACTV data and statistics are partially accessible).
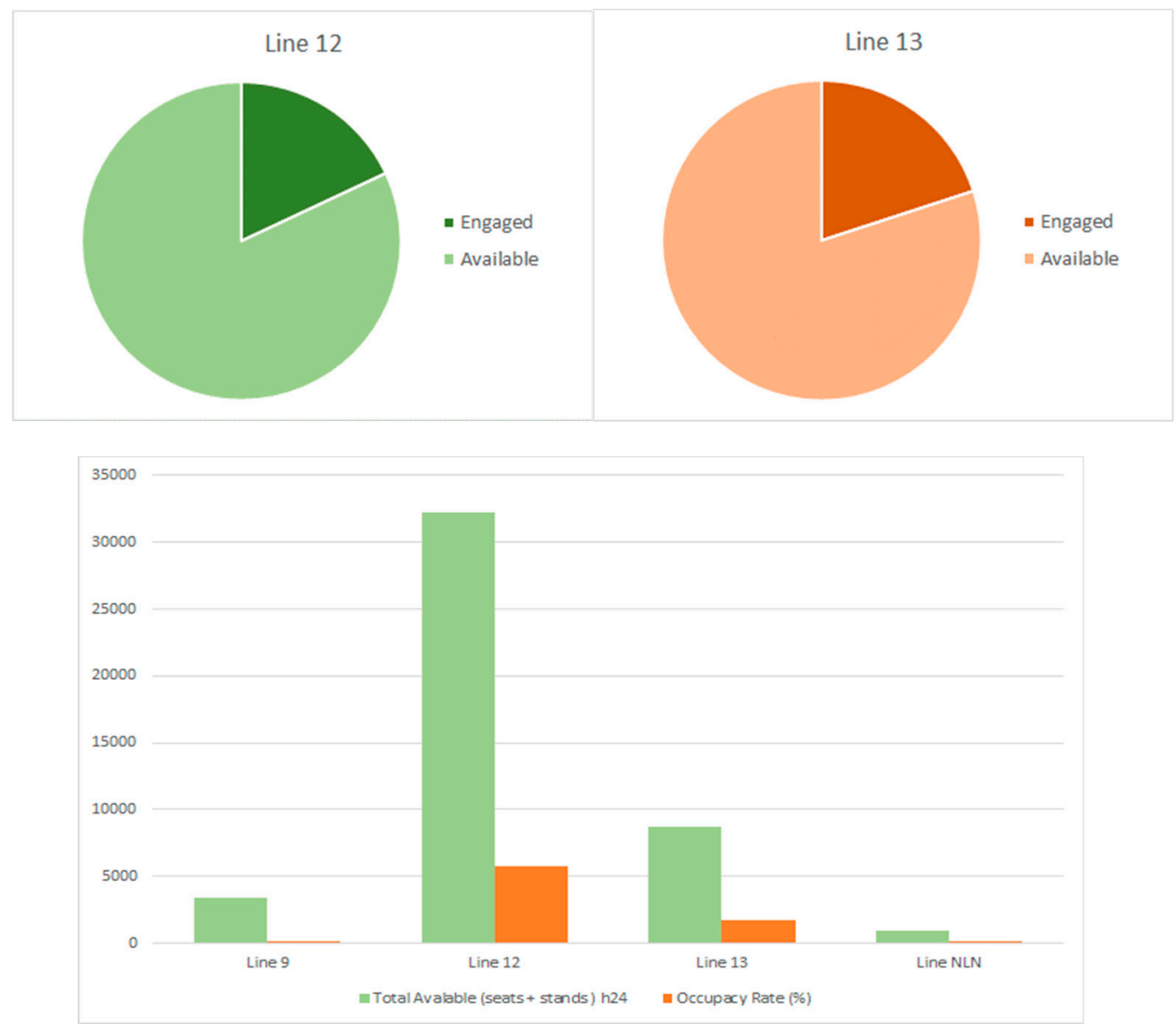

Figure 13. Public transport average occupancy rates by main lines. 
Public transport features are taken into account to eventually get an estimation of the existing available capacity (in terms of available seats) in the current ("as is") scenario, which is the necessary step to then assess the spare capacity of public transport for freight transport ("to be" scenario).

Parallel to data collection activities, events were organized to discuss specific issues and validated collected data with relevant stakeholders. Confartigianato, leading logistics operators, the Metropolitan City of Venice, the Municipality of Venice, the Regione Veneto and the general public were the main stakeholders involved.

\subsection{Data Analysis and Methods}

In this section, the main methods to elaborate and analyzed collected data are presented. The research area consists of the whole northern section of the Venice Lagoon, where a significant proportion of UFT (Urban Freight Transport) demand and public transport routes (co)exist. In particular, the historical city center of Venice plays the role of the main hub, while the islands of Murano, Burano, Torcello and S. Erasmo represent main nodes.

Following some methodologies proposed in the literature $[10,51,53]$, we develop an original scenario-building approach to assess proposed mixed transport services consisting of:

- Building the "as is" scenario (in particular, replicating main features of the existing urban logistics and mobility systems and network configuration);

- Identifying main opportunities to develop mixed passenger and freight solutions;

- Building the "to be" scenarios (simulating the optimized/improved integrated urban transport network).

The "as is" scenario provides a picture of the existing configuration of both passenger and freight logistics urban networks, and it is simulated by:

- Estimating the existing freight transport flows (demand side) and analyzing the overall urban logistics system design;

- Estimating the available capacity (supply side) of the existing public transport system.

Data sources include statistics (secondary sources), observations/surveys and interviews (primary sources) (see Section 2.1).

Once an overall picture of the two systems (passenger and freight) is elaborated, relevant opportunities to develop mixed solutions are identified. In particular, an overlapping/decomposition approach to identify the sections of the urban network suitable for mixed solutions is employed [13]. Freight and passenger networks are integrated (origins, destinations, nodes, schedules, etc.) to unlock opportunities of "combined" services.

Next, "to be" scenarios are built to optimize the urban network in the research area by focusing on the sections identified in the previous step. The "to be" scenarios are designed by integrating the two systems in the identified sections and are simulated by:

- Estimating the spare capacity of the public transport system in the research area;

- Estimating the actual freight transport demand suitable to be shifted to mixed transport solutions.

For overall scenario assessment, we employ an indicator of technical performance of the urban network (matching demand and supply dimensions) to evaluate and compare "as is"/"to be" scenarios, consisting of the reduction of unused/spare capacity of public transport. Such an indicator shows the degree of optimization of the proposed integrated urban network configuration, thus, the improvement in overall urban sustainability. Moreover, the reduction in the number of operating freight boats is also assessed.

\section{Results}

Before discussing the main results, some descriptive figures on the research area are provided. The Venice Lagoon represents a very sensitive environment in which human needs must coexist with 
preservation. It has a surface area of about 550 square kilometers, and it hosts an archipelago of 40 minor islands. Moreover, tourism plays a relevant role heavily affecting urban mobility and freight logistics in the overall area. In Tables 2 and 3, some demographic, touristic, socio-economic and transport data is provided.

Table 2. Population and tourists in the Venice Lagoon.

\begin{tabular}{ccc}
\hline & Residents & No. Tourists/Year \\
\hline Venice Lagoon System & $\mathbf{1 4 1 , 2 7 7}$ & $\mathbf{2 5 , 8 0 0 , 0 0 0}$ \\
\hline Venice City Center & 58,666 & $25,800,000$ \\
Chioggia & 50,764 & $1,460,000$ \\
Litorale del Lido & 17,848 & 912,500 \\
Murano & 4968 & $2,190,000$ \\
Litorale di Pellestrina & 4471 & 146,000 \\
Burano & 3267 & $1,277,500$ \\
S.Erasmo & 771 & 91,250 \\
Mazzorbo & 364 & 54,750 \\
Le Vignole & 69 & 21,000 \\
Torcello & 25 & 350,000 \\
Mazzorbetto & 10 & 3500 \\
San Clemente & 1 & 2000 \\
San Giorgio Maggiore & 11 & 100,000 \\
San Lazzaro degli Armeni & 22 & 1500 \\
San Michele & 11 & 100,000 \\
San Francesco del Deserto & 9 & 12,000 \\
\hline
\end{tabular}

Table 3. Transport system in the Venice Lagoon: Some summary figures.

\begin{tabular}{ccc}
\hline Type & No. & $\%$ \\
\hline Freight Boats & 9110 & 28.37 \\
Water-Taxis & 12,407 & 38.64 \\
Tourist Shuttles & 833 & 2.59 \\
Leisure Boats & 2995 & 9.33 \\
Row-Boats & 1557 & 4.85 \\
Waterbus-Public Transport Service & 4639 & 14.45 \\
Tug boats-Fishing boats & 82 & 0.26 \\
Garbage Boats & 470 & 1.46 \\
Others & 16 & 0.05 \\
Total & 32,109 & 100 \\
\hline
\end{tabular}

\subsection{The Existing Urban Mobility System ("As Is" Scenario)}

\subsubsection{The Urban Freight Transport and Logistics System}

To get freight flow estimates and an overall picture of the existing urban freight transport and logistics system, relevant data sources (both secondary and primary) are used and integrated according to the overall methodology design (see Section 2.2).

Main urban logistics nodes used by operators are those of Tronchetto-operating most of the traffic-and Treporti. Although Tronchetto is certainly the most important urban logistics node for UFT in Venice, Treporti is significantly used during the summertime, when transport flows towards the islands (Burano, Torcello, etc.) increase and direct shipments strategies turn out to be convenient. In fact, it is more convenient for suppliers located in the hinterland (e.g., production and distribution companies) to ship their goods to Treporti during the summer, thus, shorten overall urban delivery routes and avoid the heavily congested node of Tronchetto.

Major customers of urban logistics operators on the islands include: 
- Restaurants (representing the largest market share);

- Shopkeepers;

- Laundries;

- Bakeries (Typical Venetian biscuits ("bussolai") are no more produced on the islands, rather in specialized plants in the hinterland);

- Hotels;

- Drugstores;

- Coffee shops;

- Souvenir shops;

- Apparel shops;

- Individuals (private customers) and families (direct deliveries to final customers (generated by Amazon, Zalando, etc. on-line shopping) have increased dramatically in recent years).

Couriers (both traditional and express) represent relevant suppliers of urban logistics operators and production/distribution companies located in the hinterland.

The main type of goods and categories operated are:

- Food (urban food supply chains should be distinguished between those managing perishable goods (fresh fish, fruits and vegetables, milk, meat) and those operating non-perishable products (beverage, tomatoes, etc.). The former requires operators to be equipped with reefer spaces onboard and they constitute a totally different kind of logistics chain, characterized by tight levels of service);

- Laundry items (tablecloths, etc.);

- Souvenirs (masks, etc.);

- Drugs;

- Luggage;

- Clothes;

- Consumer goods (detergents, paper, etc.).

In what follows, some pictures of various types of goods and related types of boats are shown (Figures 14 and 15).

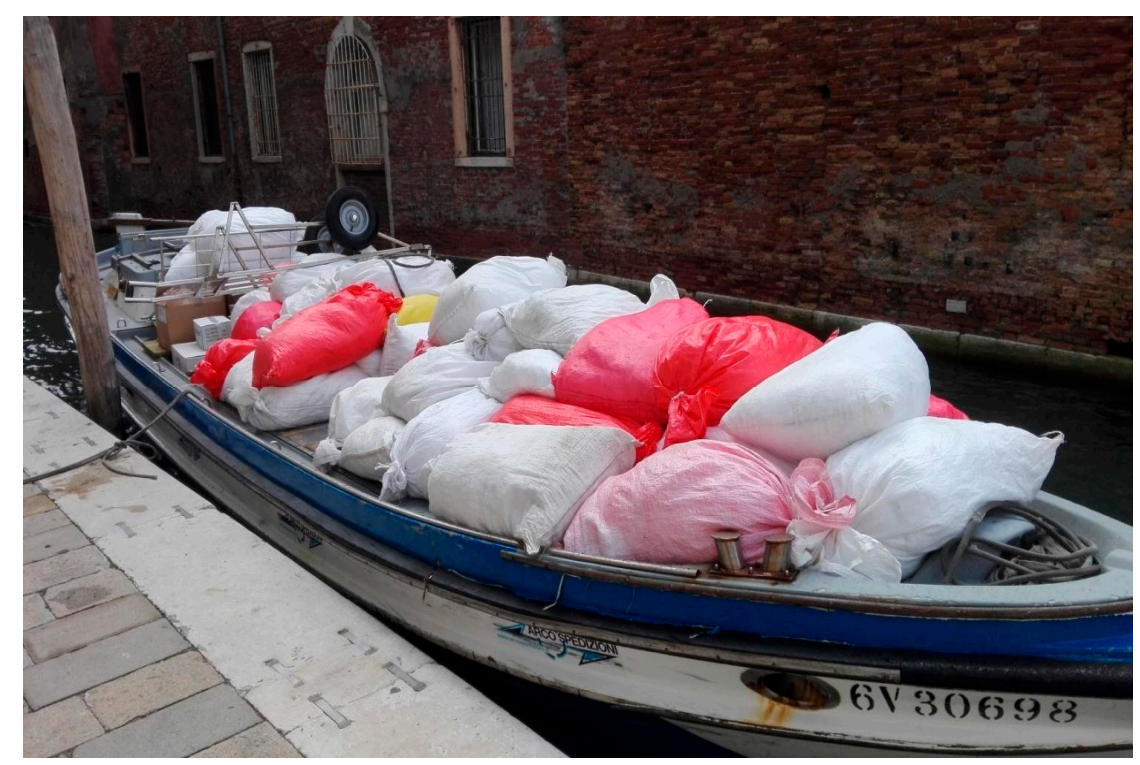

Figure 14. Urban freight transport-laundry. 


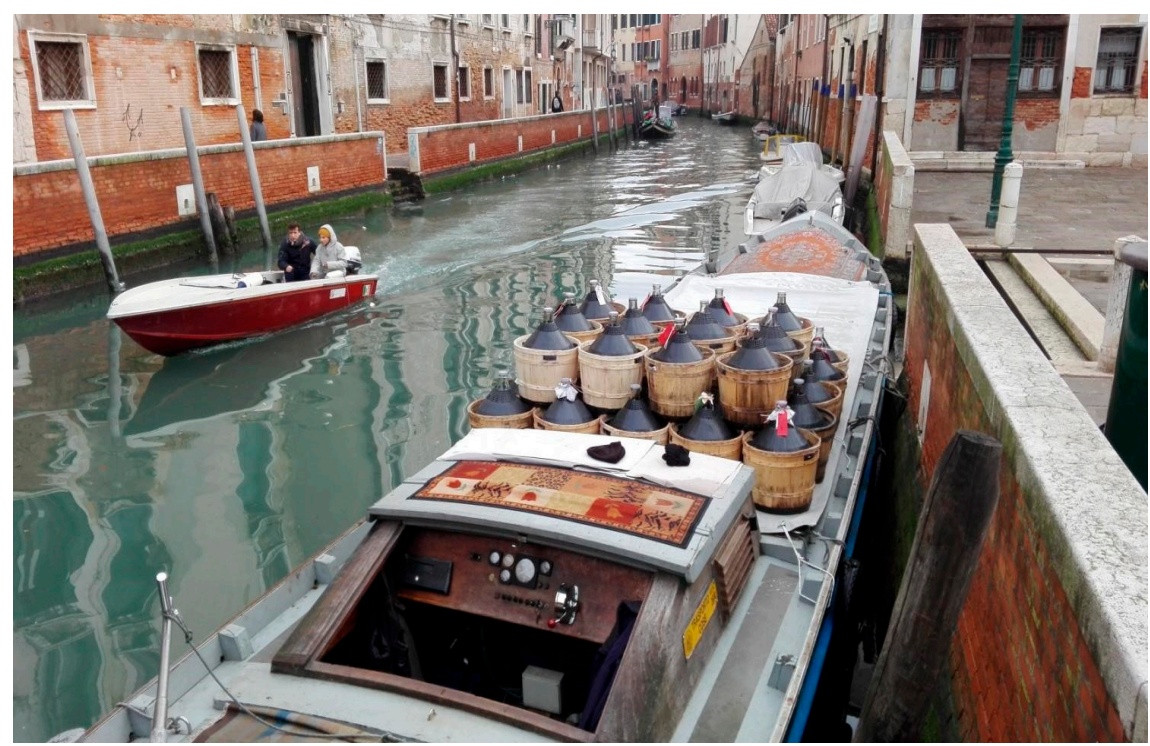

Figure 15. Urban freight transport-beverage.

Urban logistics providers specialized in operations on island connections follow some regular routing patterns (Figure 16).

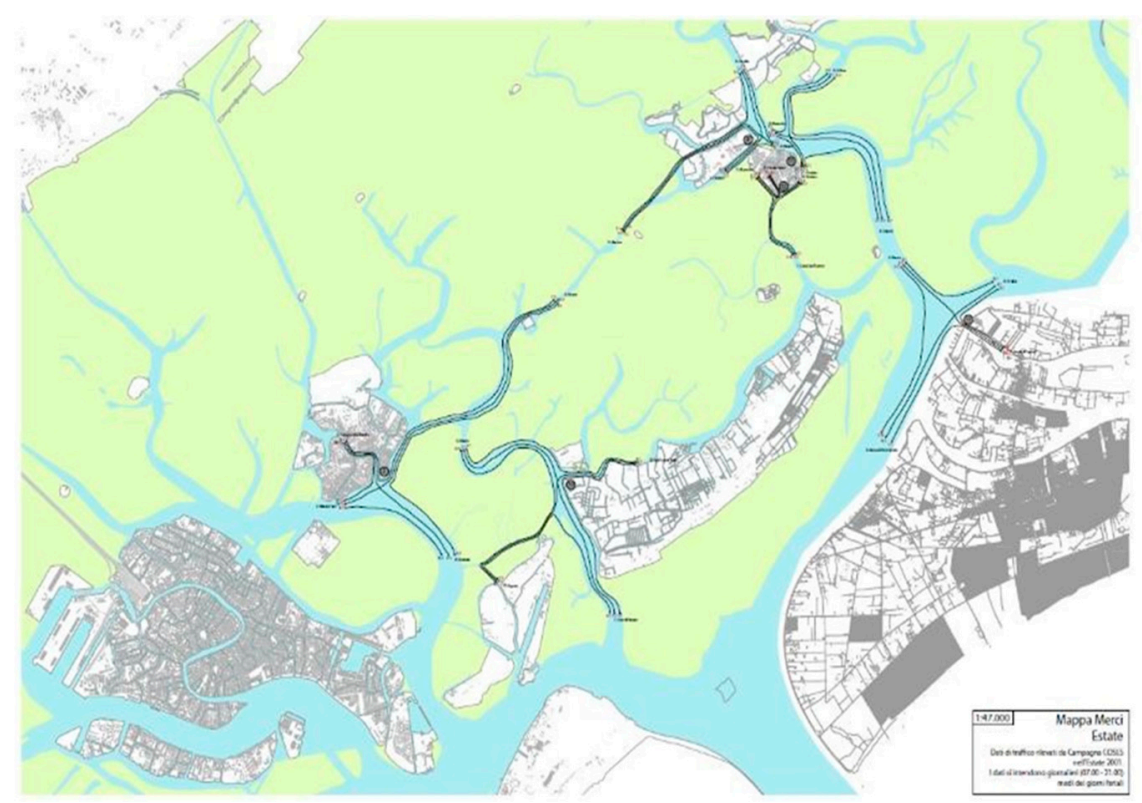

Figure 16. Freight transport main routing patterns.

In particular, some operators serve both Venice (historical city center) and the islands, while others are strictly specialized on islands operations. The first category adopts the following logistics network strategies:

- Direct deliveries to the islands from Tronchetto: Large shipment sizes-mostly, food products—are operated every 15 days. They ensure a full load factor, while employing dedicated boats;

- Indirect deliveries: Small/medium shipment sizes are consolidated at Tronchetto, then deliver to Venice first and subsequently to the islands (multidrop delivery pattern). As for scheduling issues, loading operations are performed at Tronchetto at 07:30-08:00, while customers on the islands receive the goods by 16:00-16:30. 
Operators strictly specialized in island connections (that is, not serving Venice historical city center) usually perform loading operations at Tronchetto or Treporti at 05:30-06:00 and then make direct deliveries to the islands (and pick up reverse flows, such as laundry items). During the summertime, such logistics providers manage operations two times/week from Tronchetto and 3-4 times/week from Treporti.

Seasonality of freight transport demand is of importance. Notably, some $65 \%$ of logistics operations are concentrated during the summer period for logistics operators adopting a multidrop strategy (some $80 \%$ for logistics operators adopting direct deliveries to the islands).

Multidrop logistics operators usually work about 10 hours/day, five days/week, while logistics operators strictly specialized in island connections normally work some six hours/day in the peak period, four hours/day otherwise.

Transit times represent a relevant constraint for logistics operations to/from the islands. Usually, it takes about one hour (or more) to go from Tronchetto to major islands (e.g., Burano), thus, routing patterns have to be carefully organized to ensure all deliveries are made within a working day. This is the reason why some islands (e.g., S. Erasmo) can hardly be reached with a satisfactorily level of service.

It has to be strongly underlined (this aspect was strongly emphasized by logistics operators during interviews) that the traditional logistics parameter of "load factor" turns out to be not that meaningful when organizing logistics operations. In fact, the real "saturation" factor is represented by the total number of deliveries to be performed during a working day. Load factor depends on many aspects, ranging from average shipment size, volume, weight, etc., while what counts most-as a constraint-is the ability to perform the necessary number of deliveries during the time period. Moreover, this explains why certain island destinations cannot be reached during specific round-trips, despite the availability of space/weight onboard.

Fleets are usually composed by the so-called "mototopo" type of boat-made of wood or fiberglass-employing one crewmember. Ships' carrying capacity ranges from 8 to 12 tons. It is extremely hard to give a precise estimation of fuel consumption. Operators report average weekly (for instance, $150 € / 5$ working days) or monthly expenses (for instance, some $600 €$ ). In fact, fuel consumption depends on many factors, including speed, transported weight, wave motion and streams (in particular, the MOSE project has substantially changed local streams), weather, etc.

The quality/level of logistics service varies depending on a number of factors, namely the type of goods and of the customer. In particular, perishable goods are delivered daily to restaurants and shopkeepers. Indeed, some goods, such as fresh fish have a lead time of two hours. The same is true for consolidated shipments by couriers (although they normally are of small/medium sizes, they nonetheless ensure a complete daily routing to be made via consolidation activities at urban logistics nodes. During peak periods, islands are served two times/days (in such a case, deliveries are made both from Tronchetto and Treporti in a single day). Nonperishable products are normally delivered to islands 2-3 times/week (usually, by late morning). Operators normally try to combine flows so as to get balanced operations (for instance, they delivery food products and get back dirty laundry items).

By employing and integrating all relevant data sources (in particular, ADTs on main sections of the urban network from secondary sources with primary sources (surveys at logistics platforms, interviews)), overall existing freight transport demand can be estimated in terms of cubic meters. Estimates are obtained by type of boats employed (more or less than 10 meters long) and origin-destinations. Table 4 summarizes the main results. 
Table 4. Overall existing freight transport demand (cu. m.).

\begin{tabular}{ccccccc}
\hline \multirow{2}{*}{ Routes } & $\mathbf{1}$ & $\mathbf{2}$ & $\mathbf{3}$ & $\mathbf{4}$ & $\mathbf{5}$ & $\mathbf{6}$ \\
\cline { 2 - 7 } & $\begin{array}{c}\text { Murano- } \\
\text { Burano }\end{array}$ & $\begin{array}{c}\text { Burano- } \\
\text { Murano }\end{array}$ & $\begin{array}{c}\text { Burano- } \\
\text { Treporti }\end{array}$ & $\begin{array}{c}\text { Treporti- } \\
\text { Burano }\end{array}$ & $\begin{array}{c}\text { Sant'Erasmo- } \\
\text { Treporti }\end{array}$ & $\begin{array}{c}\text { Treporti- } \\
\text { Sant'Erasmo }\end{array}$ \\
\hline No. ships $>10 \mathrm{mt}$ & 63 & 29 & 20 & 9 & 15 & 5 \\
No. ships $<10 \mathrm{mt}$ & 21 & 52 & 30 & 35 & 8 & 18 \\
Overall number of ships & 84 & 81 & 50 & 44 & 23 & 23 \\
Cubic meters transported $(>10 \mathrm{mt})$ & 2016 & 928 & 640 & 288 & 480 & 160 \\
Cubic meters transported. $(<10 \mathrm{mt})$ & 221 & 546 & 315 & 368 & 84 & 189 \\
Overall cubic meters transported & 2237 & 1474 & 955 & 656 & 564 & 349 \\
\hline
\end{tabular}

\subsubsection{The Existing Public Transport Network}

By elaborating relevant data (see Section 2.1), the existing public transport system in the research area can be represented by estimating the overall available capacity (Table 5).

Table 5. Available capacity of public transport (by lines and type of ship) in the research area.

\begin{tabular}{|c|c|c|c|c|c|c|}
\hline & & $\begin{array}{l}\text { No. } \\
\text { Seats }\end{array}$ & $\begin{array}{l}\text { No. } \\
\text { Chairs }\end{array}$ & $\begin{array}{c}\text { Overall Number of } \\
\text { Daily Trips } \\
\text { (07:00-21:00) }\end{array}$ & $\begin{array}{c}\text { Overall } \\
\text { No. Seats }\end{array}$ & $\begin{array}{l}\text { Overall } \\
\text { No. } \\
\text { Chairs }\end{array}$ \\
\hline \multicolumn{7}{|c|}{ LINE 12 (SUMMER) } \\
\hline Murano-Burano & Motobattello foraneo & 325 & 111 & 28 & 9100 & 3108 \\
\hline Burano-Murano & Motobattello foraneo & 325 & 111 & 28 & 9100 & 3108 \\
\hline Burano-Treporti & Motobattello foraneo & 325 & 111 & 27 & 8775 & 2997 \\
\hline Treporti-Burano & Motobattello foraneo & 325 & 111 & 28 & 9100 & 3108 \\
\hline Total & & & & 82 & 26,650 & 9102 \\
\hline \multicolumn{7}{|c|}{ LINE 13 (ANNUAL) } \\
\hline S. Erasmo-Treporti & Vaporetto & 218 & 81 & 13 & 2834 & 1053 \\
\hline Treporti-S.Erasmo & Vaporetto & 218 & 81 & 15 & 3270 & 1215 \\
\hline S.Erasmo-Treporti & Single driver speedboat & 40 & 40 & 16 & 640 & 640 \\
\hline Treporti-S.Erasmo & Single driver speedboat & 40 & 40 & 15 & 600 & 600 \\
\hline Total & & & & 59 & 7344 & 3508 \\
\hline
\end{tabular}

\subsection{Mixed Passenger and Freight Transport Opportunities}

The existing UFT and public transport networks are then integrated into the research area to identify main "overlapped" sections, whereby assessing specific mixed passenger and freight transport opportunities. Remarkably, since both networks turn out to show a somehow simplified configuration in the area, all relevant connections in the whole research area are eventually considered. In other words, even though our initial probable perspective was to focus on specific connections (sort of "pilot" opportunities, following a decomposition approach) to assess the feasibility of mixed/cargo hitching solutions, eventually we end up assessing all the opportunities within the whole (northern) Lagoon network.

We examine the urban logistics and mobility network sections with the aim of optimizing overall existing transport capacity, thus, improving overall logistics sustainability and performance. Opportunities to implement mixed/cargo hitching solutions can consist of:

- Physical bundling of flows on specific connections (e.g., consolidating freight and passenger flows);

- Re-scheduling options: That is, proposing optimized scheduling and time-windows policy options;

- Re-routing options: That is, proposing adjustments of existing public transport routes (e.g., close-to-origin, close-to-destination, en-route).

In this paper, we mainly consider physical bundling and some re-scheduling options (in fact, authors are currently working also on some re-routing options as further improvements of proposed solutions in the paper. In particular, the idea is to "stretch" the routing patterns of public transport to 
embed a number of close-to-origin and close-to-destination options of existing lines, while en-route variations do not seem necessary).

\subsection{An Integrated Urban Mobility System Based on Mixed Passenger and Freight Solutions ("to be" Scenarios)}

By subtracting the occupancy rates from overall public transport available capacity, the spare capacity of public transport in the research area is estimated and represented in Figure 17.

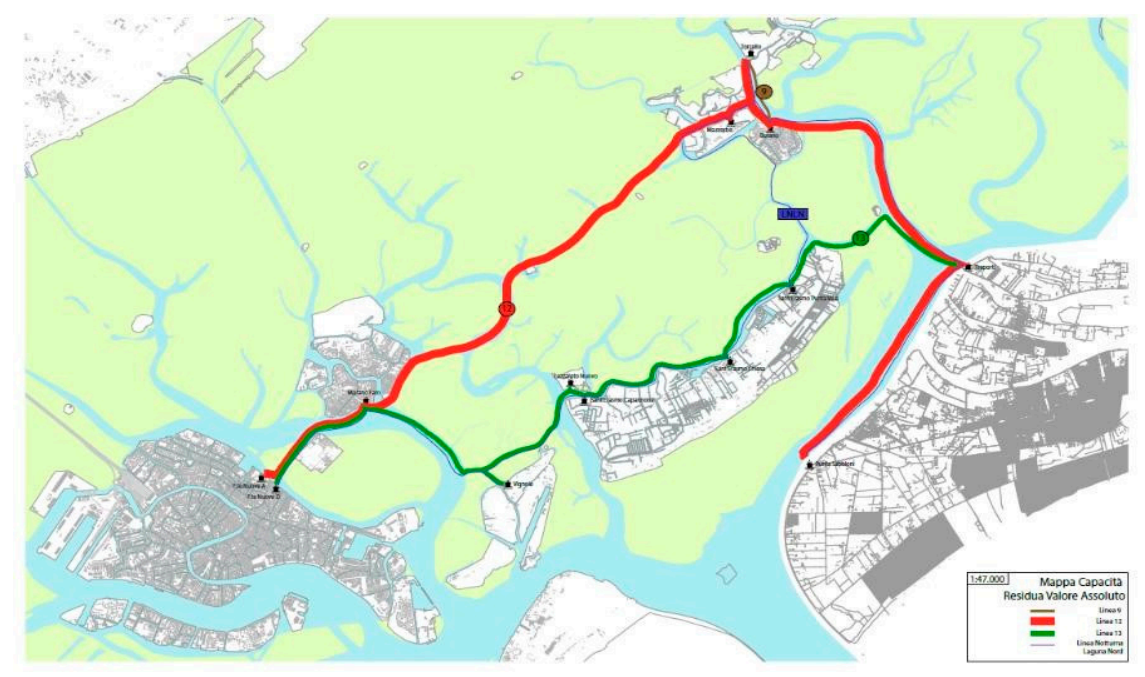

Figure 17. Public transport spare capacity by main lines.

The estimated overall spare capacity calculated in terms of seats is then transformed into square meters. An (operational) standard of four passengers/square meter is employed (standards were provided by the local public transport company). This estimation is then replicated for each line considered in the research area. In order to perform a risk assessment and improve the robustness of our estimates, the maximum rate of occupancy is used in the simulation. Moreover, an additional safety factor of $10 \%$ is considered (for a sort of "prudent" baseline scenario). Table 6 summarizes the overall estimated figures (in square meters).

Table 6. Spare capacity of public transport (sq. m).

\begin{tabular}{ccccccc}
\hline \multirow{2}{*}{ Routes } & $\mathbf{1}$ & $\mathbf{2}$ & $\mathbf{3}$ & $\mathbf{4}$ & $\mathbf{5}$ & $\mathbf{6}$ \\
\cline { 2 - 7 } & $\begin{array}{c}\text { Murano- } \\
\text { Burano }\end{array}$ & $\begin{array}{c}\text { Burano- } \\
\text { Murano }\end{array}$ & $\begin{array}{c}\text { Burano- } \\
\text { Treporti }\end{array}$ & $\begin{array}{c}\text { Treporti- } \\
\text { Burano }\end{array}$ & $\begin{array}{c}\text { Sant'Erasmo- } \\
\text { Treporti }\end{array}$ & $\begin{array}{c}\text { Treporti- } \\
\text { Sant'Erasmo }\end{array}$ \\
\hline Overall supply (No. seats) & 9100 & 9100 & 8775 & 9100 & 3474 & 3870 \\
Overall supply (No. chairs) & 3108 & 3108 & 2997 & 3108 & 1693 & 1815 \\
Overall supply (sq. m) & 2275 & 2275 & 2194 & 2275 & 869 & 968 \\
Occupancy rate (worst case) \% & 35 & 35 & 35 & 35 & 37 & 37 \\
Safety factor (\%) & 10 & 10 & 10 & 10 & 10 & 10 \\
Reference occupancy rate (\%) & 45 & 45 & 45 & 45 & 47 & 47 \\
Overall occupied surface (sq. m) & 1024 & 3204 & 987 & 1024 & 408 & 455 \\
Available surface (sq. m) & 1251 & 1251 & 1207 & 1251 & 460 & 513 \\
\hline
\end{tabular}

Next step consists of transforming the spare capacity into cubic meters, in order to get an equivalent unit to compare passenger and freight mobility. As for risk assessment, the minimum height of boats plus a precautionary risk factor of $20 \%$ (representing possible non-optimal stocking operations and packaging constraints onboard) is considered (Table 7). 
Table 7. Spare capacity of public transport (cu. m.).

\begin{tabular}{ccccccc}
\hline \multirow{2}{*}{ Routes } & $\mathbf{1}$ & $\mathbf{2}$ & $\mathbf{3}$ & $\mathbf{4}$ & $\mathbf{5}$ & $\mathbf{6}$ \\
\cline { 2 - 7 } & $\begin{array}{c}\text { Murano- } \\
\text { Burano }\end{array}$ & $\begin{array}{c}\text { Burano- } \\
\text { Murano }\end{array}$ & $\begin{array}{c}\text { Burano- } \\
\text { Treporti }\end{array}$ & $\begin{array}{c}\text { Treporti- } \\
\text { Burano }\end{array}$ & $\begin{array}{c}\text { Sant'Erasmo- } \\
\text { Treporti }\end{array}$ & $\begin{array}{c}\text { Treporti- } \\
\text { Sant'Erasmo }\end{array}$ \\
\hline Available space (cu. m.) & 2503 & 2503 & 2413 & 2503 & 921 & 1206 \\
Safety factor (\%) & 20 & 20 & 20 & 20 & 20 & 20 \\
Net available space (cu. m.) & 2002 & 2002 & 1931 & 2002 & 736 & 820 \\
\hline
\end{tabular}

At the same time, once overall existing freight transport demand in cubic meters is estimated (Table 4), it is then necessary to get the actual freight demand that can be reasonably shifted to mixed transport services (Table 8 ). This can be done by considering the type of goods and the proportion between own account and third-party operations (these figures and features of urban transport were not previously available, and they were collected in the paper (primary sources). Starting from the overall existing transport volumes of freight transport demand, the actual share that can reasonably be assigned to mixed services is determined. We consider two scenarios based on the characteristics of flows operated by the integrated system:

- "High scenario": Considering flows operated by third-party providers;

- "Low scenario": Considering flows operated by third-party providers with respect to selected types of goods. In the low scenario, only certain types of goods are considered to be suitable for the new integrated service (at least, initially). In particular, suitable goods can be those subject to more regular scheduling. They include, for instance, laundry and beverage. We do not include fresh food products, since they require specific transport requirements.

Table 8. Actual freight transport demand (cu. m.).

\begin{tabular}{|c|c|c|c|c|c|c|}
\hline \multirow[b]{2}{*}{ Routes } & 1 & 2 & 3 & 4 & 5 & 6 \\
\hline & $\begin{array}{l}\text { Murano- } \\
\text { Burano }\end{array}$ & $\begin{array}{l}\text { Burano- } \\
\text { Murano }\end{array}$ & $\begin{array}{l}\text { Burano- } \\
\text { Treporti }\end{array}$ & $\begin{array}{l}\text { Treporti- } \\
\text { Burano }\end{array}$ & $\begin{array}{c}\text { Sant'Erasmo- } \\
\text { Treporti }\end{array}$ & $\begin{array}{c}\text { Treporti- } \\
\text { Sant'Erasmo }\end{array}$ \\
\hline Overall third-party transport (cu. m.) & 1544 & 1017 & 659 & 453 & 389 & 241 \\
\hline $\begin{array}{l}\text { Third-party transport -main types of } \\
\text { goods (cu. m.) }\end{array}$ & 556 & 366 & 237 & 163 & 140 & 87 \\
\hline Overall No. third-party transport boats & 56 & 54 & 33 & 29 & 15 & 15 \\
\hline No. third-party boats (main type of goods) & 22 & 21 & 13 & 12 & 6 & 7 \\
\hline No. boats $>10 \mathrm{mt}$ & 16 & 13 & 5 & 3 & 4 & 2 \\
\hline No. boats $<10 \mathrm{mt}$ & 6 & 8 & 8 & 9 & 2 & 5 \\
\hline
\end{tabular}

Estimated transport volumes are also used to get the consequent number of freight boats to be operated. Such an estimate is needed to assess the reduced number of boats circulating in the urban system following the introduction of the mixed transport services.

Final results show that the actual freight transport demand in the two scenarios can be satisfied by the existing spare capacity of public transport via the new mixed services, thus, demonstrating the feasibility of the proposed integrated system in the research area. Consequently, a significant reduction in the number (and type) of circulating boats can be achieved.

In particular, estimates of the reduction in spare public transport capacity-meaning, the degree of optimization of the proposed urban mobility network—can be represented in Table 9 to assess overall scenarios. Indicators are reported for the two scenarios. 
Table 9. Reduction in the spare capacity of public transport.

\begin{tabular}{ccccccc}
\hline \multirow{2}{*}{ Routes } & $\mathbf{1}$ & $\mathbf{2}$ & $\mathbf{3}$ & $\mathbf{4}$ & $\mathbf{5}$ & $\mathbf{6}$ \\
\cline { 2 - 7 } & $\begin{array}{c}\text { Murano- } \\
\text { Burano }\end{array}$ & $\begin{array}{c}\text { Burano- } \\
\text { Murano }\end{array}$ & $\begin{array}{c}\text { Burano- } \\
\text { Treporti }\end{array}$ & $\begin{array}{c}\text { Treporti- } \\
\text { Burano }\end{array}$ & $\begin{array}{c}\text { Sant'Erasmo- } \\
\text { Treporti }\end{array}$ & $\begin{array}{c}\text { Treporti- } \\
\text { Sant'Erasmo }\end{array}$ \\
\hline $\begin{array}{c}\text { Spare capacity ex-ante (cu.m) } \\
\text { High Scenario: Overall third-party transport } \\
\text { demand (cu. m.) }\end{array}$ & 2002 & 2002 & 1931 & 2002 & 736 & 820 \\
$\begin{array}{c}\text { Lem Scenario: Third-party transport demand } \\
\text {-main types of goods (cu. m.) }\end{array}$ & 556 & 1017 & 659 & 453 & 389 & 241 \\
Spare capacity ex-post High Scenario (cu.m) & 458 & 366 & 237 & 163 & 140 & 87 \\
Spare capacity ex-post Low Scenario (cu.m) & 1446 & 1636 & 1694 & 1549 & 347 & 579 \\
Reduction in spare capacity High Scenario (\%) & 77 & 50 & 34 & 23 & 596 & 733 \\
Reduction in spare capacity Low Scenario (\%) & 28 & 18 & 12 & 8 & 53 & 29 \\
\hline
\end{tabular}

Reported estimates concern entire daily operations. In order for the proposed services to be even more useful to logistics operators by means of the introduction of re-scheduling options, some refined estimates can be obtained, for which a tighter time interval (time-windows) is considered (Table 10). In particular, it is shown that the entire transport demand can be operated within a time interval of about four hours, meaning that both public and freight transport can benefit. In fact, public transport can accommodate freight demand with no additional services or lines requirements, while freight transport demand can be operated during the morning hours (say, by 11.00), which is what operators require to effectively serve their customers.

Table 10. Time optimization of urban logistics operations.

\begin{tabular}{ccccccc}
\hline Routes & $\mathbf{1}$ & $\mathbf{2}$ & $\mathbf{3}$ & $\mathbf{4}$ & $\mathbf{5}$ \\
\cline { 2 - 6 } & $\begin{array}{c}\text { Murano- } \\
\text { Burano }\end{array}$ & $\begin{array}{c}\text { Burano- } \\
\text { Murano }\end{array}$ & $\begin{array}{c}\text { Burano- } \\
\text { Treporti }\end{array}$ & $\begin{array}{c}\text { Treporti- } \\
\text { Burano }\end{array}$ & $\begin{array}{c}\text { Sant'Erasmo- } \\
\text { Treporti }\end{array}$ & $\begin{array}{c}\text { Treporti- } \\
\text { Sant'Erasmo }\end{array}$ \\
\hline $\begin{array}{c}\text { Third-party transport -main types of } \\
\text { goods (cu. m.) }\end{array}$ & 556 & 366 & 237 & 163 & 140 \\
Available cubic meters per vaporetto & 72 & 72 & 72 & 72 & 46 \\
No. boats required & 8 & 5 & 4 & 3 & 2 \\
Operational hours requirements & 4 & 2.5 & 2 & 2 & 2 \\
Time period (AM) & $07: 00-11: 00$ & $07: 00-10: 00$ & $07: 00-09: 00$ & $07: 00-09: 00$ & $07: 00-09: 00$ & $07: 00-08: 00$ \\
\hline
\end{tabular}

\section{Discussion and Conclusions}

Along with the results of other studies in various urban contexts [1,2,13,31,41,43,53], our research has demonstrated the benefits-in a quantifiable (and qualitative as well) manner-of a mixed passenger and freight urban system in the Venice Lagoon in terms of increased urban performance and sustainability (optimization of the existing transport capacity). In particular, the case study has focused on peripheral areas (core-periphery connections), where few studies have been conducted so far elsewhere and never so in Venice. Moreover, the results of our paper contribute to increasing the number of good practices in Europe towards the implementation of innovative urban transport solutions based on the integration of passenger and freight systems.

The viability of the proposed urban solutions then represents the necessary step to further promote the implementation of an integrated passenger/freight transport system at the institutional level, which is a general requirement in every urban context [1] to improve overall urban sustainability $[8,21,54-57]$. Next steps for implementation consist of the revision of the current regulatory framework at a local level. In fact, the concrete implementation of such innovative solutions relies on a set of new policy rules, which must be included both at strategic (e.g., SUMP) and at the tactical level (e.g., public tenders assigning transport services to operators). Such an approach should be pursued in every urban setting and requires future research to demonstrate its feasibility (as mentioned, authors are currently working on the revision of the local regulatory framework (and the implementation of some pilot initiatives), also in other urban environments). In other words, once positive results about the feasibility of mixed solutions have been demonstrated, the integration of passenger and freight transport systems 
must necessarily rely on a strong political will (local plans and tendering procedures). Typical issues regarding integration processes should then be considered at every local level, and a balance between different needs of various stakeholders should be achieved (A similar case could be that of integrated pricing policy of public transport systems at a regional level, where new rules are the basis of new business models involving various stakeholders. In that respect, mixed passenger and freight/cargo hitching solutions and integrated pricing of public transport show similar regulatory features (clearing rules, etc.).). An integrated (passenger/freight) approach to urban mobility represents a novel feature for SUMPs and SULPs (Sustainable Logistics Plans), since traditionally the two systems are considered independently. The bottom-line idea is to promote sustainability at the urban level by exploiting innovative business models and planning approaches capable of thoroughly exploiting the existing transport capacity by unlocking opportunities of efficiency recovery.

Thus, from a wider perspective, we consider-along with the literature [14-16,45]—mixed passenger and freight transport/cargo hitching as one of the modern and innovative concepts to be promoted in future SUMPs and SULPs.

In that, some limitations of mixed passenger and freight solutions can be found. In fact, besides proving the benefits of mixed solutions at a given territorial level, a major critical issue is represented indeed by the political will of local policy-makers to implement structural reforms aimed at going beyond the separation between passenger and freight systems-as suggested by the EU Commission. Policymakers are required to take mixed solutions as a strategic principle of urban mobility with the aim to improve overall urban sustainability [54-58]. They should implement a new regulatory framework in which transport resources are shared and integrated among different systems. In order to do so, no doubt that without proving — on a mostly-quantitative basis—the feasibility of proposed solutions in a growing number of urban settings, policy-makers would possibly remain skeptical about adopting them within structural reforms. Moreover, the consolidated interests of various stakeholders represent a further limitation.

At the same time, operational, organizational and managerial challenges lay ahead also for logistics operators and transport companies. In fact, to the extent to which mixed urban transport and cargo hitching principles are taken onboard of SUMPs, tendering procedures—at a tactical level一to assign urban transport services to operators would be open to companies potentially capable of providing integrated passenger and freight services. This represents a big challenge for companies from a managerial and organizational viewpoint.

The study on mixed passenger and freight solutions in Venice paves the way to promote and implement the innovative business model and urban logistics network (re)design in other urban settings. In the main, transferability and generalization issues focus on the strategic principle of mixed solutions/cargo hitching to foster an integrated SUMP in which both passenger and freight transport must be considered altogether in a coordinated way. Moreover, looking at the generalization of the results in Venice, we would identify specific urban structures in which mixed solutions could be particularly suitable and effective. Two kinds of urban structures can be envisaged, namely:

- Urban structures characterized by significant urban sprawl, that is, an urban center and a large number of far distant "satellites", where distances are meaningfully considered in terms of travel times. In this respect, cargo hitching constitutes an effective transport solution and a suitable business model capable of optimizing core-periphery connections ("weak" arcs) in a more economically-viable manner within an extended/distributed urban network. This way, the model is also scalable at a metropolitan or regional level indeed;

- Strong touristic features of the urban context, along with a significant environmental sensitivity.

Indeed, such urban structures can be referred to a number of general urban models found in literature, in particular:

- New towns $[59,60]$;

- Metropolitan areas [61-63]; 
- Garden city [64,65] (Coincidentally, Howard's urban structure shows a "central city" population similar to Venice's, let alone the naming of central transportation axis called "Grand Canal" (!)) (Figure 18).

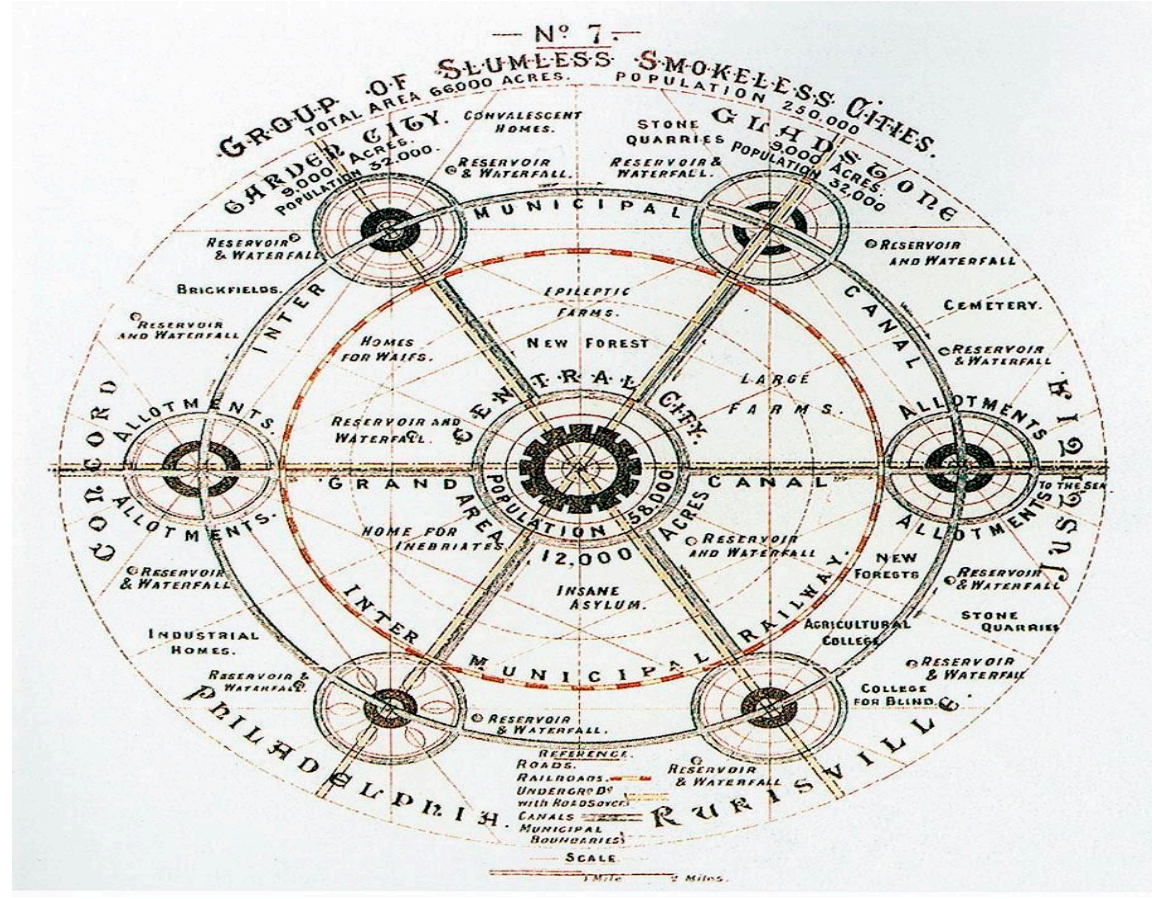

Figure 18. The Howard's model.

Author Contributions: M.M. is responsible for paragraphs 1, 1.1, 2, 3 and 4 as for the methodology, validation, analysis, resources, data curation, writing and editing, supervision, funding acquisition. L.R. contributed to data requirements, collection and analysis in the second paragraph (2.1.1 in particular).

Funding: The research was partially funded by the NOVELOG Project (new cooperative business models and guidance for sustainable city logistics (Horizon 2020) funded by the European Commission's Horizon 2020 Programme for Research and Innovation under grant agreement No 636626.

Acknowledgments: The authors wish to thank Paolo Menegazzo of the Venice Port Authority, Confartigianato Venezia and Alessandro Bracale at IUAV for significantly supporting data collection, analysis and scenario-building activities.

Conflicts of Interest: The authors declare no conflict of interest.

\section{References}

1. Masson, R.; Trentini, A.; Lehuédé, F.; Malhéné, N.; Péton, O.; Tianhig, H. Optimization of a city logistics transportation system with mixed passengers and goods. EURO J. Transp. Logist. 2017, 6, 81-109. [CrossRef]

2. Gonzalez-Feliu, J.; Morana, J. Collaborative transportation sharing: From theory to practice via a case study from France. In Technologies for Supporting Reasoning Communities and Collaborative Decision Making: Cooperative Approaches; IGI Global: Hershey, PA, USA, 2011; pp. 252-271.

3. Wefering, F.; Rupprecht, S.; Buhrmann, S.; Bohler-Baedeker, S. Guidelines Developing and Implementing a Sustainable Urban Mobility Plan; European Platform on Sustainable Urban Mobility Plans: Brussels, Belgium, 2013.

4. Gonzalez-Feliu, J.; Semet, F.; Routhier, J.L. (Eds.) Sustainable Urban Logistics: Concepts, Methods and Information Systems; Springer: Berlin/Heidelberg, Germany, 2014.

5. Taniguchi, E. Concepts of city logistics for sustainable and liveable cities. Procedia Soc. Behav. Sci. 2014, 151, 310-317. [CrossRef] 
6. May, A. Encouraging good practice in the development of Sustainable Urban Mobility Plans. Case Stud. Transp. Policy 2015, 3, 3-11. [CrossRef]

7. Arsenio, E.; Martens, K.; di Ciommo, F. Sustainable urban mobility plans: Bridging climate change and equity targets? Res. Transp. Econ. 2016, 55, 30-39. [CrossRef]

8. Okraszewska, R.; Romanowska, A.; Wolek, M.; Oskarbski, J.; Birr, K.; Jamroz, K. Integration of a multilevel transport system model into susainable urban mobility planning. Sustainability 2019, 10, 479. [CrossRef]

9. Lindholm, M. A sustainable perspective on urban freigh transport: Factors affecting local authorities in the planning procedures. Procedia Soc. Behav. Sci. 2010, 2, 6205-6216. [CrossRef]

10. Gonzalez-Feliu, J.; Pronello, C.; Grau, J. Multi-stakeholder collaboration in urban transport: State-of-the-art and research opportunities. Transport 2018, 33, 1079-1094. [CrossRef]

11. Neghabadi, P.D.; Espinouse, M.L.; Samuel, K.E. Planning process for pooling integration in city logistics. In Proceedings of the 4th International Conference on Logistics Operations Management (GOL), Le Havre, France, 10-12 April 2018.

12. Standing, C.; Standing, S.; Biermann, S. The implications of the sharing economy for transport. Transp. Rev. 2019, 39, 226-242. [CrossRef]

13. Trentini, A.; Malhene, N. Flow management of passengers and goods coexisting in the urban environment: Conceptual and operational points of view. Procedia Soc. Behav. Sci. 2012, 39, 807-817. [CrossRef]

14. Gakis, K.; Pardalos, P. Network Design and Optimization for Smart Cities; World Scientific: Singapore, 2017.

15. Faulin, J.; Grasman, S.; Juan, A.; Hirsch, P. Sustainable Transportation and Smart Logistics; Elsevier: Amsterdam, The Netherlands, 2019.

16. van Duin, J.; Wiegmans, B.; Tavasszy, L.; Hendriks, B.; He, Y. Evaluating New Participative City Logistics Concepts: The Case of Cargo Hitching. Transp. Res. Procedia 2019, 39, 565-575. [CrossRef]

17. Ghilas, V.; Demir, E. Integrating passenger and freight transportation: Model formulation and insights. In Beta Working Papers; Technische Universiteit Eindhoven: Eindhoven, The Netherlands, 2013; Volume 441.

18. Bothun, D.; Lieberman, M.; Egol, M.; Clarke, D.; Atkinson, J.; Blumenthal, J.; Decker, B.; Hobbs, M.; Shirsekar, S. The Sharing Economy; Pricewaterhouse Coopers: London, UK, 2015.

19. Hamari, J.; Sjokling, M.; Ukkonen, A. The sharing economy: Why people participate in collaborative consumption. J. Assoc. Inf. Sci. Technol. 2015, 67, 2047-2059. [CrossRef]

20. Noy, K.; Givoni, M. Is "Smart Mobility" Sustainable? Examining the Views and Beliefs of Transport's Technological Entrepreneurs. Sustainability 2018, 10, 422. [CrossRef]

21. Visvizi, A.; Lytras, M. Sustainable Smart Cities and Smart Villages Research: Rethinking Security, Safety, Well-being and Happiness. MDPI Books. 2018. Available online: https://www.mdpi.com/journal/ sustainability/special_issues/smart_cities_smart_villages?view=compact\&listby=date (accessed on 14 May 2019).

22. Neirotti, P.; de Marco, A.; Cagliano, A.; Mangano, G.; Scorrano, F. Current trends in Smart Cities initiatives: Some stylised facts. Cities 2014, 38, 25-36. [CrossRef]

23. Batty, M. Big data, smart cities and city planning. Dialogues Hum. Geogr. 2013, 3, 274-279. [CrossRef] [PubMed]

24. Angelidou, M. Smart city policies: A spatial approach. Cities 2014, 41, 3-11. [CrossRef]

25. Meijer, A.; Bolivar, M. Governing the smart city: A review of the literature on smart urban governance. Int. Rev. Adm. Sci. 2015, 81, 392-408. [CrossRef]

26. Gesing, B. Sharing Economy Logistics: Rethinking Logistics with Access Over Ownership; DHL Customer Solutions \% Innovation; DHL: Troisdorf, Germany, 2017.

27. Jansen, T. Integrated Passenger and Freight Transportation System. Master's Thesis, Edinhoven University of Tehcnology, Eindhoven, The Netherlands, 2014.

28. Lu, M. Innovative Solutions for sustainable urban freight transport. In Proceedings of the 21st World Congress on Inteligent Transport Systems: Reinventing Transportation in Our Connected World, Detroit, MI, USA, 7-11 September 2014.

29. Commission, E. Green Paper on Urban Mobility; European Commision: Brussels, Belgium, 2007.

30. Trentini, A.; Mahléne, E.N. Toward a Shared Urban Transport System Ensuring Passengers \& Goods Cohabitation. J. Land Use Mobil. Environ. 2010, 3. [CrossRef]

31. Fatnassi, E.; Chaouachi, J.; Klibi, W. Planning and operating a shared goods and passengers on-demand rapid transit system for sustainable city logistics. Transp. Res. Part B 2014, 81, 440-460. [CrossRef] 
32. Anderson, S.; Allen, J.; Browne, M. Urban logistics—How can it meet policy makers sustainability objectives? J. Transp. Geogr. 2005, 13, 71-81. [CrossRef]

33. Munuzuri, J.; Larraneta, J.; Onieva, L.; Cortes, P. Solutions applicable by urban administrations for urban logistics improvements. Cities 2005, 22, 15-28. [CrossRef]

34. Bakker, J. Increasing Delivery Efficiency by Cargo Hitching: A Case Study. Master's Thesis, TU/e School of Industrial Engineering, Eindhoven, The Netherlands, 2015.

35. Commission, E. Towards Competitive and Resource Efficient Urban Mobility; European Commission: Brussels, Belgium, 2013.

36. Sikkens, C. Stakeholder Involvement in Integrated Passenger and Freight Transportation: An Exploratory Study in The Netherlands; University of Groningen: Groningen, The Netherlands, 2014.

37. Baoxiang, L. Optimization of People and Freight Transportation-Pickup and Delivery Problems Variants. Ph.D. Thesis, TU/e Eindhoven University of Technology, Eindhoven, The Netherlands, 2015.

38. Spoor, J. Replenishment Nanostores in Megacities for a Consumer Packaged Goods Company. Master's Thesis, TU/e School of Industrial Engineering, Eindhoven, The Netherlands, 2015.

39. Quak, H. Sustainability of Urban Freight Transport. Retail Distribution and Local Regulations in Cities; Erasmus Research Institute Management (ERIM): Rotterdam, The Netherlands, 2015; ISBN 978-90-5892-154-3.

40. Venne, J. Designing a Downstream Revenue Model for an Integrated Passenger and Freight Transport System, Survey Research; NHTV: Breda, The Netherlands, 2017.

41. Pternea, M.; Lan, C.L.; Haghani, A.; Chin, S. A feasibility study for last-mile synergies between passenger and freight transport for an urban area. In Proceedings of the Annual Meeting of Transportation Research Board 2018, Washington, DC, USA, 7-11 January 2018.

42. Chiffi, C. Delivering Goods by Cargo Tram in Amsterdam (Netherlands); Eltis: Brussels, Belgium, 2015.

43. Baindur, D.; Macàrio, R. Mumbai lunch box delivery system: A transferable benchmark in urban logistics? Res. Transp. Econ. 2013, 38, 110-121. [CrossRef]

44. He, Y. Responsible Regional Integrated Passenger and Freight Transportation: Business Model Analysis-A Case Study in Millingen aan de Rijn; Delft University of Technology: Delft, The Netherlands, 2017.

45. Arvidsson, S.; Givoni, M.; Woxenius, J. Exploring Last-Mile Synergies in Passenger and Freight Transport. Built Environ. 2016, 42, 523-538. [CrossRef]

46. Kant, G.; Quak, H.; Peeters, R.; van Woensel, T. Urban freight transportation: Challenges, Failures and Successes. In Logistics and Supply Chain Innovation: Bridging the Gap between Theory and Practice; Springer: Berlin/Heidelberg, Germany, 2016; pp. 127-139.

47. Savelsbergh, M.; van Woensel, T. City Logistics: Challenges and Opportunities. Transp. Sci. 2016, 50, 579-590. [CrossRef]

48. Macàrio, R.; Galelo, A.; Martins, P. Business models in urban logistics. Ing. Desarro. 2008, 24, 77-96.

49. Behiri, W.; Belmokhtar-Berraf, S.; Chu, C. Urban freight transport using passenger rail network: Scientific issues and quantitative analysis. Transp. Res. Part E Logist. Transp. Rev. 2018, 115, 227-245. [CrossRef]

50. Allen, J.; Ambrosini, C.; Browne, M.; Patier, D.; Routhier, J.; Woodburn, E.A. Data collection for understanding urban goods movement. In Sustainable Urban Logistics: Concepts, Methods and Information System; Springer: Berlin/Heidelberg, Germany, 2014; pp. 71-89.

51. Ballou, R.H. Business Logistics/Supply Chain Management; Pearson Prentice Hall: Upper Saddle River, NJ, USA, 2004.

52. Ferrozzi, C.; Shapiro, R. Dalla Logistica al Supply Chain Management; ISEDI: Torino, Italy, 2006.

53. Palacios-Arguello, L.; Gonzalez-Feliu, J.; Gondran, N.; Badeig, F. Assessing the economic and environmental impacts of urban food systems for public school canteens: Case study of Great Lyon region. Eur. Transp. Res. Rev. 2018, 10, 37. [CrossRef]

54. Yigitcanlar, T.; Kamruzzaman, M. Planning, Development and Management of Sustainable Cities: A Commentary from the Guest Editors. Sustainability 2015, 7, 14677-14688. [CrossRef]

55. Louro, A.; da Costa, N.M.; da Costa, E.M. Sustainable Urban Mobility Policies as a Path to Healty Cities-The Case Study of LMA, Portugal. Sustainability 2019, 11, 2929. [CrossRef]

56. De Souza, J.V.R.; De Mello, A.M.; Marx, R. When Is an Innovative Urban Mobility Business Model Sustainable? A Literature Review and Analysis. Sustainability 2019, 11, 1761. [CrossRef]

57. Santos, G. Sustainability and Share Mobility Models. Sustainability 2018, 10, 3194. [CrossRef]

58. Holden, E.; Gilpin, G.; Banister, D. Sustainable Mobility at Thirty. Sustainability 2019, 11, 1965. [CrossRef] 
59. Hardy, D. From Garden Cities to New Towns; Routledge: London, UK, 2003.

60. Alonso, W. What are new towns for? Urban Stud. 1970, 7, 37-55. [CrossRef]

61. Clapp, J. New Towns and Urban Policy: Planning Metropolitan Growth; Dunellen: New York, NY, USA, 1971.

62. Wheeler, S. Regions, megaregions and sustainability. Reg. Stud. 2009, 43, 863-876. [CrossRef]

63. Wheeler, S. Planning for metropolitan sustainability. J. Plan. Educ. Res. 2000, 20, 133-145. [CrossRef]

64. Howard, E. Garden Cities of To-Morrow; Swan Sonnenschein \& Co. Ltd.: London, UK, 1902.

65. Sharifi, A. From garden city to eco-urbanism: The quest for sustainable neighborhood development. Sustain. City Soc. 2016, 20, 1-16. [CrossRef]

(C) 2019 by the authors. Licensee MDPI, Basel, Switzerland. This article is an open access article distributed under the terms and conditions of the Creative Commons Attribution (CC BY) license (http://creativecommons.org/licenses/by/4.0/). 